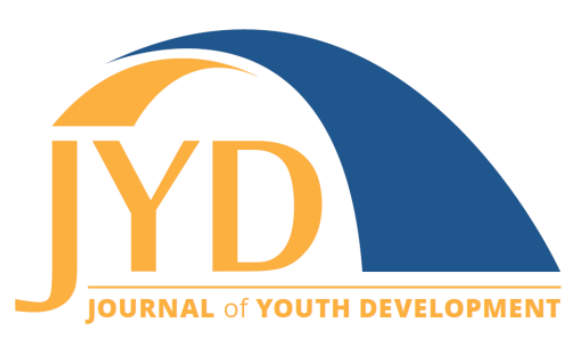

http://jyd.pitt.edu/ | Vol. 16 Issue 2-3 DOI 10.5195/jyd.2021.1046 | ISSN 2325-4017 (online)

\title{
Listening to Youth Through 17 Cross-Sectoral Youth Assessments: Implications for Programming and Policy
}

\author{
Cassandra Jessee \\ International Center for Research on Women \\ cassandra.jessee@gmail.com \\ Audrey Marie Moore \\ Mathematica Policy Research \\ amoore@mathematica-mpr.com \\ Christy Olenik \\ Making Cents International \\ christy@makingcents.com \\ Chelsea Pallatino Trevelline \\ Making Cents International \\ chelsea@makingcents.com \\ Nancy Taggart \\ U.S. Agency for International Development (USAID) \\ nataggart@usaid.gov
}

\section{Abstract}

Between 2015 and 2020, USAID invested in 17 country-focused and regional youth assessments to investigate young people's priorities and needs. This article analyzes the results of those assessments and their implications for youth programming and policy in low-and middle-income countries. Primary data collection, document review, and secondary data analysis form the basis for the findings presented in the article. Our analysis across all assessments focused on identifying the most marginalized and vulnerable youth within each country of focus and understanding youth's priorities and the barriers and facilitators for achieving them across the sectors. Securing a decent livelihood was the top priority cited by youth in each of the 17 assessments. The youth saw education as a step towards self-reliance and a better future. Older youth recognized the importance of gaining tangible work-related skills and wanted more opportunities to learn and apply these skills. Health priorities related to mental health, substance abuse prevention, and reproductive health, specifically early pregnancy. Young people expressed frustration that 
adults and society writ large do not hear their voices and acknowledged limited opportunities to develop leadership roles. Youth in conflict or unstable contexts expressed a strong desire to engage in their society. Common implications focus on sectoral programming, research, and policy using a positive youth development framework, acknowledging the importance of any program to foster cross-sectoral collaboration. Building awareness, improving coordination, and increasing the skills of actors supporting youth development-and ensuring youth are at the center of these efforts-increase the effectiveness and consistency of youth programming and policies as part of the enabling environment.

Key words: international positive youth development, cross-sectoral youth assessments, youth programming, workforce development, livelihood, education, health, civic engagement, youth participation, peace and security

\section{Introduction}

Globally there are 2.45 billion youth aged 10 to 29 , and that number will reach nearly 2.57 billion by 2030 (United Nations Department of Economic and Social Affairs Population Dynamics, 2020). In many low- and middle-income countries (LMICs), youth make up over $50 \%$ of the population. Governments and donors view this "youth bulge" as both a challenge and an opportunity for economic development and the social sectors (Lord, 2016). Between 2015 and 2020, the U.S. Agency for International Development (USAID) invested in 17 country-focused and regional youth assessments across sub-Saharan Africa, Eurasia, Latin America, and the Caribbean. These assessments used qualitative methods to gather data from young people on their needs and priorities. The results helped USAID prioritize 5-year plans related to youth programming strategies.

The assessments used the positive youth development (PYD) framework to understand youth, assets, agency, contribution, and factors in the enabling environment that impact their success. PYD is a strengths-based framework derived from developmental systems theory (Lerner et al., 2005). It emerges when "the potential plasticity of human development aligns with developmental assets." (Lerner et al., 2005). USAID contributed to developing the PYD framework used in this article (USAID, 2012). It draws on previous PYD frameworks (Benson et al., 1998; Catalano et al., 2002; Eccles \& Gootman, 2002; Lerner, 2002, 2004) and is defined as "[engaging] youth along with their families, communities, and governments so that youth are empowered to reach their full potential. PYD approaches build skills, assets, and competencies; foster healthy relationships; strengthen the environment; and transform systems" (Catalano et al., 2019, p. 17).

This article leverages USAID investments in these assessments and uses it as an opportunity to share information collected on the experiences of youth globally. The discussion uses PYD's 
strength-based perspective to contribute to the international literature and implementation practices in three crucial ways. First, it highlights common PYD programming strengths across these 17 assessments, highlighting successful interventions. Second, the article notes common, and at times extensive challenges youth increasingly face that government and donor programming are not addressing. Finally, it highlights unique and interesting differences based on age, sex, and geographical focus. We hope that our findings contribute to improved international PYD programming and highlight implications for youth-focused policy.

\section{Research Questions and Methodology}

This study's methodology uses qualitative multi-case analysis of the 17 youth assessments ${ }^{1}$ that USAID-funded YouthPower Learning and YouthPower2: Learning and Evaluation (YP2LE) implemented from 2015 to 2020. Research teams conducted the assessments across subSaharan Africa, Eurasia, Latin America, and Caribbean regions. Each of the 17 cross-sectoral youth assessments (CSYAs) included a core set of research questions based on the local context. Central questions for the youth assessments:

1. What are the characteristics of marginalized and vulnerable youth whom USAID prioritizes for programming? ${ }^{2}$

2. What assets do youth possess (e.g., soft and technical skills, access to and use of technology) to help them achieve their goals?

3. What are youth's agency or motivations (e.g., their priorities for their own future)?

4. How do youth engage and contribute in their families and communities?

5. What is the role of the enabling environment in the youth space, including structural and institutional capacity; geographic and cultural nuances and diversity; and influences of global issues, such as migration, human trafficking, and the drug trade?

The authors collected the youth assessments, developed themes to guide the multi-case review, grouped data from each assessment by sector, and synthesized the findings. The findings based on the 17 youth assessments seek to provide insights into the following questions:

1. What do youth voices teach us about positive youth development?

2. What can youth program implementers, governments, and donors learn from these assessments that contributes to addressing the ongoing challenges youth face worldwide?

\footnotetext{
${ }^{1}$ For the purposes of this article, each assessment is considered a "case."

${ }^{2}$ Six of the assessments were underway or started after the COVID-19 lockdown regulations, which further accentuated an exploration on themes around youth and vulnerability.
} 
Table 1 summarizes the two main components of data collection used for this study.

Table 1. Study Components, Research Questions, and Data Sources

\begin{tabular}{|c|c|c|c|}
\hline Research question & $\begin{array}{l}\text { Component 1: } \\
\text { Individual } \\
\text { country youth } \\
\text { assessments }\end{array}$ & $\begin{array}{l}\text { Component II: } \\
\text { Multi-case } \\
\text { review and } \\
\text { analysis }\end{array}$ & Data sources \\
\hline $\begin{array}{l}\text { What are the characteristics of marginalized } \\
\text { and vulnerable youth whom USAID } \\
\text { prioritizes for programming? }\end{array}$ & $x$ & & $\begin{array}{l}\text { - Key informant interviews } \\
\text { - Focus group discussions } \\
\text { - Administrative data } \\
\text { - Surveys } \\
\text { - Secondary literature review }\end{array}$ \\
\hline $\begin{array}{l}\text { What assets do youth possess that assist } \\
\text { them in achieving their goals? }\end{array}$ & $x$ & & $\begin{array}{l}\text { - Key informant interviews } \\
\text { - Focus group discussions } \\
\text { - Surveys }\end{array}$ \\
\hline What is youth's agency or motivation? & $x$ & & $\begin{array}{l}\text { - Key informant interviews } \\
\text { - Focus group discussions }\end{array}$ \\
\hline $\begin{array}{l}\text { How do youth engage and contribute in their } \\
\text { families and communities? }\end{array}$ & $x$ & & $\begin{array}{l}\text { - Key informant interviews } \\
\text { - Focus group discussions }\end{array}$ \\
\hline $\begin{array}{l}\text { What is the role of the enabling } \\
\text { environment? }\end{array}$ & $X$ & & $\begin{array}{l}\text { - Key informant interviews } \\
\text { - Focus group discussions } \\
\text { - Surveys } \\
\text { - Secondary literature review }\end{array}$ \\
\hline $\begin{array}{l}\text { What do youth voices teach us about } \\
\text { positive youth development? }\end{array}$ & & $x$ & - Country youth assessments \\
\hline $\begin{array}{l}\text { What can youth program implementers, } \\
\text { governments, and donors learn from these } \\
\text { assessments that help address challenges } \\
\text { youth face worldwide? }\end{array}$ & & $X$ & - Country youth assessments \\
\hline
\end{tabular}

\section{Cross-Sectoral Youth Assessments}

YouthPower Learning and YP2LE researchers designed the data collection tools as rapid exploratory youth assessments (Green et al., 2020). The assessments used mixed methods to gather insights from youth and local stakeholders about youth (Education Development Center, 2009). The sample frame for each assessment included youth ages 18 to 35 across urban and rural areas of 17 countries. ${ }^{3}$ The youth sample represented a cross-section of young people, including those from vulnerable and marginalized populations. The sample size of youth included in each assessment varied by country but ranged from eight in Madagascar to 7,801 in Kenya. The average number of youth that participated in the assessments across countries was 178. The team used convenience or snowball sampling to conduct the focus groups and interviews in the individual countries. While the samples were diverse, they are not considered representative of all target populations.

\footnotetext{
${ }^{3}$ For Eastern and Southern Caribbean, virtual field research included Barbados, Grenada, Guyana, Saint Lucia, and Trinidad and Tobago.
} 
Primary data sources for the rapid country assessments included focus group discussions (FGDs) with young people and key informant interviews (KIIs) with stakeholders from youthserving organizations, national and local government, international donors, key business entities, and community leaders. In addition, a review of administrative data sets and, in a few cases, surveys were included. During the COVID-19 pandemic, the youth assessments used online surveys to gather additional data from youth since the assessment teams were unable to conduct in-person focus group discussions. Table 2 provides a summary of the number of focus groups and KIIs by country assessment. The average number of focus groups across the assessments was 22, and the average number of KIIs was 46.

Table 2. Purpose and Methodology of the Youth Assessments Reviewed

\begin{tabular}{|c|c|c|}
\hline $\begin{array}{l}\text { Country - Year of assessment } \\
\text { (Assessment) }\end{array}$ & Purpose of the assessment & $\begin{array}{l}\text { Age range } \\
\text { No. of FGDs } \\
\text { Total youth } \\
\text { No. of KIIs }\end{array}$ \\
\hline \multicolumn{3}{|c|}{ Africa } \\
\hline $\begin{array}{l}\text { Democratic Republic of the } \\
\text { Congo - } 2017 \\
\text { (Blum et al., 2017; Woolf et al., } \\
\text { 2017) }\end{array}$ & $\begin{array}{l}\text { Capture what affects young people in the eastern Democratic } \\
\text { Republic of the Congo (DRC) and consider their role in the } \\
\text { peaceful transformation and stabilization of their country that } \\
\text { can inform activity design. }\end{array}$ & $\begin{array}{l}15-35 \\
16 \\
150 \\
25\end{array}$ \\
\hline $\begin{array}{l}\text { Ethiopia - } \mathbf{2 0 1 7} \\
\text { (Boyson et al., 2017; Desta et al., } \\
\text { 2018) }\end{array}$ & $\begin{array}{l}\text { Understand the status and aspirations of Ethiopian youth in } \\
\text { their journey from adolescence to adulthood to guide future } \\
\text { programming. }\end{array}$ & $\begin{array}{c}15-29 \\
24 \\
177 \\
54\end{array}$ \\
\hline $\begin{array}{l}\text { Guinea - } \mathbf{2 0 2 0} \\
\text { (Sengezener \& Mansare, 2020a, } \\
\text { 2020b) }\end{array}$ & $\begin{array}{l}\text { Capture the experiences, aspirations, challenges, and assets of } \\
\text { Guinean youth and identify effective programs, organizations, } \\
\text { and partnerships supporting youth that can inform the next } \\
\text { USAID Country Development Cooperation Strategy (CDCS). }\end{array}$ & $\begin{array}{l}15-35 \\
20 \\
125 \\
21\end{array}$ \\
\hline $\begin{array}{l}\text { Kenya - } 2020 \\
\text { (Rutherford \& Mirzoyants, 2020) }\end{array}$ & $\begin{array}{l}\text { Understand who are vulnerable and marginalized youth to } \\
\text { develop recommendations that can guide future programming. }\end{array}$ & $\begin{array}{l}\mathbf{1 5 - 3 4} \\
23 \\
\mathbf{7 , 8 0 1 ^ { a }} \\
18\end{array}$ \\
\hline $\begin{array}{l}\text { Liberia - } 2018 \\
\text { (Blum, 2018; Blum et al., 2019) }\end{array}$ & $\begin{array}{l}\text { Use a PYD lens to capture the experiences of Liberian youth } \\
\text { across sectors to inform the CDCS and the design of a future } \\
\text { integrated youth activity. }\end{array}$ & $\begin{array}{l}\mathbf{1 5 - 3 5} \\
30 \\
\mathbf{2 7 5} \\
79\end{array}$ \\
\hline $\begin{array}{l}\text { Madagascar - } 2020 \\
\text { (Green \& Andrianaivosoa, 2020) }\end{array}$ & $\begin{array}{l}\text { Analyze the status of youth, youth policy, and youth } \\
\text { development in Madagascar to inform strategic planning and } \\
\text { targeting for future programming as well as the next CDCS. }\end{array}$ & $\begin{array}{c}10-24 \\
-- \\
8 \\
34\end{array}$ \\
\hline $\begin{array}{l}\text { Mauritania - } 2020 \\
\text { (Barsa \& Sidatt, 2020) }\end{array}$ & $\begin{array}{l}\text { Understand the drivers of violent extremism (VE) among youth } \\
\text { and to identify strategies to prevent VE to apply findings to } \\
\text { redesign the main bilateral youth activity. }\end{array}$ & $\begin{array}{c}16-35 \\
16 \\
189 \\
58\end{array}$ \\
\hline $\begin{array}{l}\text { Morocco - } \mathbf{2 0 2 0} \\
\text { (Tihm et al., 2020) }\end{array}$ & $\begin{array}{l}\text { Assess the current status and challenges of youth in Morocco } \\
\text { across sectors to inform the next CDCS and future activity } \\
\text { designs }\end{array}$ & $\begin{array}{l}15-34 \\
-- \\
138 \\
37\end{array}$ \\
\hline $\begin{array}{l}\text { Nigeria - } 2015 \\
\text { (Making Cents International, 2016) }\end{array}$ & $\begin{array}{l}\text { Assess the youth employment landscape to inform project } \\
\text { design. }\end{array}$ & $\begin{array}{c}15-30 \\
7 \\
68 \\
--\end{array}$ \\
\hline
\end{tabular}


Table 2. (continued)

\begin{tabular}{|c|c|c|}
\hline $\begin{array}{l}\text { Country - Year of assessment } \\
\text { (Assessment) }\end{array}$ & Purpose of the assessment & $\begin{array}{l}\text { Age range } \\
\text { No. of FGDs } \\
\text { Total youth } \\
\text { No. of KIIs }\end{array}$ \\
\hline \multicolumn{3}{|c|}{ Africa } \\
\hline $\begin{array}{l}\text { Rwanda - } 2019 \\
\text { (Green et al., 2019) }\end{array}$ & $\begin{array}{l}\text { Understand the status, aspirations, and challenges of } \\
\text { Rwandan youth to inform the next CDCS and a new integrated } \\
\text { activity }\end{array}$ & $\begin{array}{l}16-30 \\
24 \\
180 \\
30\end{array}$ \\
\hline $\begin{array}{l}\text { Somalia - } 2019 \\
\text { (Rutherford et al., 2019, 2020) }\end{array}$ & $\begin{array}{l}\text { Understand the status of youth using a PYD lens and models } \\
\text { for future programming that can be used to inform the next } \\
\text { CDCS. }\end{array}$ & $\begin{array}{c}15-30 \\
30 \\
283 \\
130\end{array}$ \\
\hline $\begin{array}{l}\text { Zambia - } 2016 \\
\text { (Walker et al., 2016) }\end{array}$ & $\begin{array}{l}\text { Understand existing programming challenges and } \\
\text { opportunities, review youth policies and strategies, and } \\
\text { consider the views of youth to inform a new CDCS. }\end{array}$ & $\begin{array}{l}18-24 \\
17 \\
\sim 128 \\
50\end{array}$ \\
\hline \multicolumn{3}{|c|}{ Eurasia } \\
\hline $\begin{array}{l}\text { Armenia - } 2019 \\
\text { (Allison et al., 2019) }\end{array}$ & $\begin{array}{l}\text { Understand the drivers that motivate youth, identify the } \\
\text { obstacles or constraints that undermine their contributions to } \\
\text { Armenia's political, economic, and social well-being in order to } \\
\text { inform the next CDCS and design of new activities. }\end{array}$ & $\begin{array}{c}15-29 \\
22 \\
170 \\
50\end{array}$ \\
\hline $\begin{array}{l}\text { Kyrgyz Republic - } \mathbf{2 0 1 9} \\
\text { (Bell et al., 2019) }\end{array}$ & $\begin{array}{l}\text { Use a PYD lens to investigate the contextual landscape, needs, } \\
\text { and assets of Kyrgyz youth to guide future USAID Mission } \\
\text { priorities. }\end{array}$ & $\begin{array}{c}14-28 \\
32 \\
317 \\
42\end{array}$ \\
\hline \multicolumn{3}{|c|}{ Latin America and the Caribbean } \\
\hline $\begin{array}{l}\text { Dominican Republic } \mathbf{c}^{\mathbf{b}} \mathbf{2 0 2 0} \\
\text { (Olenik et al., 2020) }\end{array}$ & Understand the status of youth in the Dominican Republic. & $\begin{array}{c}10-24 \\
-- \\
-- \\
12\end{array}$ \\
\hline $\begin{array}{l}\text { Eastern and Southern Caribbean } \\
-\mathbf{2 0 2 0} \\
\text { (Nicholson \& Walker, 2020) }\end{array}$ & $\begin{array}{l}\text { Understand the status and aspirations of youth to inform a } \\
\text { regional strategy and future activities in the Eastern and } \\
\text { Southern Caribbean region. }\end{array}$ & $\begin{array}{l}10-29 \\
15 \\
206^{a} \\
28\end{array}$ \\
\hline $\begin{array}{l}\text { Honduras - } \mathbf{2 0 1 8} \\
\text { (Catsum \& Castro, 2019; Catsum et } \\
\text { al., 2018) }\end{array}$ & $\begin{array}{l}\text { Understand the aspirations of and challenges facing youth in } \\
\text { Western Honduras to guide programming in one specific } \\
\text { development objective. }\end{array}$ & $\begin{array}{c}18-29 \\
31 \\
242 \\
44\end{array}$ \\
\hline
\end{tabular}

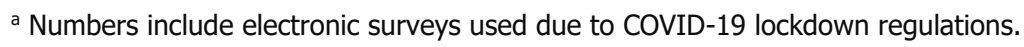

${ }^{\mathrm{b}}$ The assessment in the Dominican Republic did not include data collection activities with youth participants.

\section{Multi-Case Analyses}

The authors used Clarke et al.'s (2015) six-phase qualitative analysis process to identify themes across the 17 youth assessments. The approach included the following steps: 
1. Familiarization of the data. Each author read and re-read five to six youth assessments to be familiar with the methodology, findings, and policy implications for the assessments. $^{4}$

2. Generating initial codes. The team worked together to agree on an initial set of codes, which included methodology type, findings by PYD domain, sectors covered by the assessment, and policy implications by age group and sector. We also created a code for youth quotes.

3. Searching for themes. Each author looked for themes in their respective reports and recorded the findings into a spreadsheet.

4. Reviewing the themes. The authors met weekly to review themes and adjusted the categories as needed.

5. Defining and naming themes. The authors used NVIVO for final coding around PYD domains, opportunities and challenges, youth vulnerability, and policy implications to analyze word frequency and create basic cross-tabulations.

6. Present findings. The findings of the analysis are presented in the results section of this article.

\section{Limitations}

\section{Depth of Research}

The original assessments were limited by the amount of time the teams had in each country and sample sizes, which were purposefully selected. For this desk review, the team focused on the final situational analysis, strategic priorities, or program description documents written by each assessment team. The assessment results frame findings in that context.

\section{Consistency of Research}

We adapted each assessment for its country or regional context along with the focus of donor interests. Key research questions varied in both focus and number across the assessments. The questions also covered the range of sectors and scanned a breadth of stakeholders. Beginning in March 2020, the COVID-19 pandemic required researchers to move to remote/virtual data collection. Researchers switched to virtual interviews or online surveys to reach youth, impacting the depth of youth voice in the assessments. The lack of consistency in the questions across the 17 assessments, different stakeholders, and approaches in each youth assessment means that the results presented in this article represent higher-level themes drawn across countries.

\footnotetext{
${ }^{4}$ Additionally, article authors were also designers, technical reviewers and/or authors of many of the other assessment reports.
} 


\section{Findings}

This article begins by defining the target populations, which include the most vulnerable youth. The subsequent sections examine youth needs and priorities by sector to understand what donors, governments, and communities can do to improve the delivery of strength-based youth programming.

\section{Who are the Most Vulnerable Youth?}

Vulnerability is "relative and dynamic" (International Federation of Red Cross and Red Crescent, 2020, para. 1). Youth vulnerabilities have multiple causes and can manifest in numerous ways (Chowa et al., 2021). Each country's definition of who was considered vulnerable differed slightly but included socio-economic level; educational attainment; religious, racial, and ethnic background; disability status; and gender; age, and sexual orientation status. Youth participants shared their conceptualizations of vulnerability and living "in a perpetual state of nervousness" (LGBTI Youth, Kyrgyz Republic), trading off agency (e.g., independent decision making) "for basic needs, such as food and safety/protection, and accept[ing] the consequences of such a tradeoff, including abuse, manipulation, and misrepresentation"(Youth, Kenya), and feeling that "society tells you that your existence is wrong...society wants you to change who you are" (Youth, Honduras). Table 3 summarizes the vulnerable populations identified by youth and other informants in each country as described in the related report for each assessment.

Each country assessment we reviewed had many nuances around marginalization issues and vulnerability that Table 3 does not capture. For example, gender (including issues related to LBGTQ), disability, and employment were the most common categories described by youth worldwide. Women continue to struggle, facing challenges of early marriage, discrimination, exploitation, and violence. All youth indicated that they struggle to find employment that allows them to reach their goals (e.g., owning a car, home, and having a family). Unemployment and underemployment issues often lead to youth making unhealthy choices, such as engaging in drugs, violence or losing hope.

We also noticed regional patterns in how youth characterized marginalization. Youth in Latin America and Caribbean assessments focused more on crime, violence, incarceration, and gangs. In contrast, youth in Eurasia indicated that marginalization was more related to ethnic group differences and underemployment. African youth faced the most diverse marginalization issues 
Journal of Youth Development | http://jyd.pitt.edu/ | Vol. 16 Issue 2-3 DOI 10.5195/jyd.2021.1046 Listening to Youth: Program and Policy Implications

from gender and disabilities to serious issues around violence, exploitation, human trafficking, and school drop-out.

Table 3. Youth Segments Identified as Vulnerable

\begin{tabular}{|c|c|c|c|c|c|c|c|}
\hline \multirow[t]{2}{*}{ Country } & \multicolumn{7}{|c|}{ Factors characterizing vulnerability } \\
\hline & $\begin{array}{c}\text { Gender, } \\
\text { including } \\
\text { LGBTQ }\end{array}$ & Disability & $\begin{array}{l}\text { Out-of- } \\
\text { school }\end{array}$ & $\begin{array}{c}\text { Exploited, } \\
\text { homeless, IDP }\end{array}$ & $\begin{array}{l}\text { Engaged or at } \\
\text { risk for violence }\end{array}$ & $\begin{array}{l}\text { Human } \\
\text { trafficking }\end{array}$ & $\begin{array}{l}\text { Unemployed } \\
\text { or under- } \\
\text { employed }\end{array}$ \\
\hline \multicolumn{8}{|c|}{ Africa } \\
\hline DRC & $\mathrm{X}$ & $\mathrm{X}$ & $\mathrm{X}$ & $\mathrm{X}$ & $\mathrm{X}$ & $\mathrm{X}$ & $\mathrm{X}$ \\
\hline Ethiopia & $\mathrm{X}$ & & & $\mathrm{X}$ & & $\mathrm{X}$ & $\mathrm{X}$ \\
\hline Guinea & $\mathrm{X}$ & & $\mathrm{X}$ & $\mathrm{X}$ & $\mathrm{X}$ & & $X$ \\
\hline Kenya & $\mathrm{X}$ & & $\mathrm{X}$ & $X$ & & & $\mathrm{X}$ \\
\hline Liberia & $\mathrm{X}$ & $\mathrm{X}$ & $\mathrm{X}$ & $\mathrm{X}$ & & & $\mathrm{X}$ \\
\hline Madagascar & $\mathrm{X}$ & & & & & & $\mathrm{X}$ \\
\hline Mauritania & & & $\mathrm{X}$ & & $\mathrm{X}$ & & \\
\hline Morocco & $\mathrm{X}$ & $\mathrm{X}$ & $\mathrm{X}$ & & & & $\mathrm{X}$ \\
\hline Rwanda & $\mathrm{X}$ & $\mathrm{X}$ & $\mathrm{X}$ & & & & $\mathrm{X}$ \\
\hline Somalia & $\mathrm{X}$ & $\mathrm{X}$ & $\mathrm{X}$ & $\mathrm{X}$ & $\mathrm{X}$ & $\mathrm{X}$ & $\mathrm{X}$ \\
\hline Zambia & $\mathrm{X}$ & $\mathrm{X}$ & & & $\mathrm{X}$ & & \\
\hline \multicolumn{8}{|c|}{ Eurasia } \\
\hline Armenia & $\mathrm{x}$ & $\mathrm{X}$ & & & & & \\
\hline $\begin{array}{l}\text { Kyrgyz } \\
\text { Republic }\end{array}$ & $x$ & $\mathrm{X}$ & & & & & $\mathrm{X}$ \\
\hline \multicolumn{8}{|c|}{ Latin America and the Caribbean } \\
\hline $\begin{array}{l}\text { Dominican } \\
\text { Republic }\end{array}$ & $\mathrm{x}$ & $\mathrm{X}$ & & $\mathrm{x}$ & $\mathrm{x}$ & & \\
\hline $\begin{array}{l}\text { Eastern and } \\
\text { Southern } \\
\text { Caribbean }\end{array}$ & & & & & $\mathrm{X}$ & & \\
\hline Honduras & $\mathrm{X}$ & & & & $\mathrm{X}$ & & \\
\hline
\end{tabular}

\section{Youth Voices From the Field}

Health, education, and livelihoods are interlinked and affect youth outcomes: unhealthy youth miss more school, perform poorly, and lack the skills they may need to find productive work. Rising rates of teenage pregnancy negatively affect school attendance and hinder girls from obtaining pre-requisites to future opportunities. - Summary of Youth Perspectives, Somalia

\section{What Do Youth Voices Teach Us About Workforce Development and Livelihoods?}

We are facing enormous challenges in the world of work today. According to the International Labour Organization (ILO), approximately 68 million youth globally are unemployed, and an additional 41 million youth will enter the workforce by 2030 . The unemployment rate among youth ages 15 to 24 was approximately 13.3 percent in 2019, and youth are twice as likely as 
adults to be unemployed. ILO data from 2016 show 39.1 percent of youth who were available and actively seeking work were unemployed. (ILO, 2020). The high unemployment rates correlate to the lack of job opportunities, discrimination, nepotism in hiring practices, weak education infrastructure, and a dearth of training opportunities that can be translated directly into income-generating activities (United Nations Children's Fund, 2019). Unemployment and underemployment issues continue rising due to the pandemic and subsequent slow economic growth (United Nations, 2020).

\section{Youth Needs and Priorities}

The issues of unemployment, underemployment, exclusion, and inequity in the workforce were pervasive across the 17 countries. Securing a decent livelihood was the top priority cited by youth ages 18 to 34 in each of the 17 assessments. Formal employment was most desirable, but youth perceive succeeding as an entrepreneur as more attainable. See Table 4 for additional youth perspectives.

Table 4. Youth Perspectives on Workforce and Livelihood Challenges

\begin{tabular}{|l|l|}
\hline Country & \multicolumn{1}{|c|}{ Youth Perspectives noted in the CSYAs } \\
\hline Guinea & $\begin{array}{l}\text { "We look good 'on paper' when you see our résumé. However, we have no practical, market- } \\
\text { relevant skills when we graduate. It is easier to make your own job." } \\
\text { "When you are a woman and have money, you are highly respected in the community and your } \\
\text { voice will surely be counted in decision making." }\end{array}$ \\
\hline Kyrgz Republic & $\begin{array}{l}\text { The acute issue is not in the absence of the jobs but also that jobs do not meet the requirements } \\
\text { of youth and all the labor force that are in the Kyrgyz Republic. }\end{array}$ \\
\hline Zambia & The transition from school to decent work is one of the greatest priorities for Zambian youth. \\
\hline
\end{tabular}

Starting their own businesses was a prominent theme across six CYSA. However, youth noted that they lack an understanding of complex start-up procedures; have few role models; and little access to credit, which prevents entrepreneurship from becoming a viable option for most youth. Several young people in Ethiopia noted that youth are resentful that the government is not providing adequate support for job creation, nor are they providing the preconditions for government-run credit schemes. The government-run programs, such as the Youth Revolving Fund, are too onerous to be accessible by most youth.

As the analysis of these CYSAs shows, young people in many countries are not content with their current employment status. Youth in the Kyrgyz Republic migrate internationally to obtain better-paid employment, leading to a loss of human capital. Rural youth in Guinea, Kenya, Liberia, Nigeria, Rwanda, and Somalia often stay at home because they have nothing to do for work. Those youth who manage to find temporary opportunities are typically underemployed, with many subjected to poor working conditions and labor rights violations. Young women face 
security issues traveling to and from work and sexual harassment in the workplace. Women in Liberia noted that gender norms were most prominent in the livelihoods domain, particularly in societal pressures and discrimination toward women. Most temporary labor opportunities are within the country's expansive informal sectors and offer no employment contracts, social security, or guarantee of a livable wage.

\section{Opportunities for Strategic Engagement}

Countries are trying to address employment barriers through a variety of means, including the development of better labor-management information systems (e.g., Honduras), but more than half of the countries reviewed in this analysis lack efficient implementation mechanisms among key regional and local stakeholders to promote youth employment and few, if any, have formal, online labor market information (LMI) systems to support employment searches. Youth indicated that one of the most significant barriers to employment was nepotism and the importance of "whom you know" rather than hiring based on skill. Discriminatory hiring practices disproportionately affect women, youth living with disabilities, and minority groups. Even when hired, young women often face sexual harassment in the office environment. Other barriers include a skills mismatch of job market entrants with employers' requirements (e.g., soft and language skills, practical experience) and the limited capacity of regional, provincial, and local government bodies to drive local economic development and create economic opportunities for youth based on proven models.

While youth face many challenges entering the workforce, participants in these assessments still believe that job training programs can help them obtain better employment, particularly if the training includes a follow-up path to income generation. Table 5 showcases several programs that serve as models for building youth employability skills.

These successful programs ${ }^{5}$ have several things in common. First, almost all of them draw on the private sector to upskill youth and marry the education sector's misalignment to the workforce needs. Second, across all these countries, the government and the private sector recognize the role of self-employment in creating viable employment paths for youth. The private sector-and in some cases the government-are stepping up to offer credit and support to help youth start businesses. Youth hubs and incubators also help youth engage and help each other contribute to economic development. These interventions and programs support

\footnotetext{
${ }^{5}$ Success in the case of these programs is defined at meeting the outcomes set out in the scope of work for the programs; level of private sector engagement; continuation of the activity beyond its original program cycle.
} 
youth who wanted to start their businesses and often led successful youth to come back and teach and mentor their peers. Finally, collaboration is critical among youth, the donor community, the private sector, and the government. Results in addressing youth employment issues are most successful when parties listen to youth voices, make them a part of the solution, and work together to reach the goal.

\section{Table 5: Exemplar Programs Building Youth Employability Skills}

\begin{tabular}{|c|c|c|}
\hline Country & Program & Purpose \\
\hline \multirow[t]{2}{*}{ Armenia } & Organization of Cooperatives & Corporate support for youth start-ups and small enterprises. \\
\hline & $\begin{array}{l}\text { EU4Youth and Lifelong Learning } \\
\text { Network }\end{array}$ & $\begin{array}{l}\text { Offers demand-driven training in sectors, such as information and } \\
\text { communication technology (ICT) and agriculture. }\end{array}$ \\
\hline \multirow[t]{2}{*}{$\begin{array}{l}\text { Dominican } \\
\text { Republic }\end{array}$} & $\begin{array}{l}\text { Juventud y Empleo (New } \\
\text { Employment and Opportunities } \\
\text { for Youth, NEO-DR) }\end{array}$ & $\begin{array}{l}\text { Seek to improve employment opportunities for low-income youth } \\
\text { living in urban areas. These programs offer post-secondary } \\
\text { connections for students, assisting them in their transition to the } \\
\text { workforce, including free training, stipends, internships, and job } \\
\text { placement assistance. NEO-DR also works to support policies that } \\
\text { promote youth employment. }\end{array}$ \\
\hline & A Ganar & $\begin{array}{l}\text { Used a model of sports to impact youth employment and taught } \\
\text { teamwork, communication, and hard work. }\end{array}$ \\
\hline \multirow[t]{2}{*}{ Kenya } & Lynk & $\begin{array}{l}\text { Harnesses ICT to create a technology platform for informal-sector } \\
\text { workers. Lynk vets workers and invests in onboarding and upskilling. } \\
\text { The programs also provide logistics and warehousing support, } \\
\text { material wholesaling, and ongoing skill training. }\end{array}$ \\
\hline & Digital Divide Data (DDD) & $\begin{array}{l}\text { Recruits disadvantaged youth (ages17-24) from urban slums to } \\
\text { participate in a training and employment program, providing digital } \\
\text { content services to DDD clients. }\end{array}$ \\
\hline Liberia & $\begin{array}{l}\text { Excellence in Higher Education for } \\
\text { Liberian Development (EHELD), } \\
\text { Presidents Young Professional } \\
\text { Program (PYPP) }\end{array}$ & $\begin{array}{l}\text { Develops youth skills and workforce readiness, including accelerated } \\
\text { learning programs for out-of-school youth, demand-driven training, } \\
\text { job intermediation, and entrepreneurship. }\end{array}$ \\
\hline
\end{tabular}

What Do Youth Voices Teach Us About Education?

We value education and believe it should be the path to better employment, but it isn't, due to social norms, nepotism, discrimination, and corruption.

- Summary of Youth Perspectives, Somalia, Rwanda, and the Kyrgyz Republic

Education worldwide expanded exponentially as a result of initiatives such as the sustainable development goals (SDGs), Education for All, donor investments, and government priorities (Robinson \& Winthrop, 2016). Gross enrollment rates in many low- and middle-income countries are above $100 \%$, and net enrollment in primary education in these countries averages from $80 \%$ to $90 \%$ (World Bank, 2018). The rate at which LMICs have improved educational access is impressive. The United States took nearly 40 years to increase girls' enrollment from 27 percent to $88 \%$-countries like Morocco have closed the gap in less than 11 years (World Bank, 2018). 
The 17 CYSAs universally reflect these changes. In these countries, gross enrollment rates range on the low end with $30 \%$ in Somalia to $14 \%$ in Madagascar, and an average gross enrollment of $95 \%$ across the sample. Gross enrollment in secondary education is lower, ranging from $20 \%$ in Zambia to $95 \%$ in the Kyrgyz Republic. The average gross enrollment in secondary education across the sample is $51 \%$.

\section{Youth Needs and Priorities}

The improvement of education in these countries was aided both by international donor presence and the importance that governments have increasingly placed on improving access to and quality of education. Across these assessments, the youth participants saw education as a step towards self-reliance and a better future-younger youth idealized education as a pathway out of poverty. Older youth recognized the importance of gaining tangible work-related skills and wanted more opportunities to learn and apply these skills. See Table 6 for additional youth perspectives.

\section{Table 6. Youth Perspectives on Education Challenges}

\begin{tabular}{|c|c|}
\hline Country & Youth Perspectives noted in the CSYAs \\
\hline Guinea & $\begin{array}{l}\text { "We believe education from high school and enrolment in higher education will facilitate better } \\
\text { employment. } \\
\text { "Youth who complete their education have better prospects than those who drop out." }\end{array}$ \\
\hline Liberia & $\begin{array}{l}\text { "Young people need domestic programs, to help youths from different backgrounds, through grants, } \\
\text { loans and scholarships. When these grants and loans are given there should be programs that will train } \\
\text { those youths in strengthening them in business skills and how to manage their income. The educational } \\
\text { sector needs to be strengthened through regular monitoring and evaluation. Teachers are not equipped, } \\
\text { we need teacher training programs; because of this young people are graduating but when tested they } \\
\text { do not perform on the job." }\end{array}$ \\
\hline Mauritania & $\begin{array}{l}\text { "I don't want to be a housewife and stay at home. It is true that a woman is destined to get married, but } \\
\text { we can get married without becoming a housewife and staying home. I can be a married woman but, at } \\
\text { the same time, work and contribute to the development of my country, because I study, have diplomas } \\
\text {. . I I dream of having a job that will empower me, make me a better person, and help me serve the } \\
\text { nation." } \\
\text { "You must make your own future with your own hands! Education helps us do that" }\end{array}$ \\
\hline Morocco & $\begin{array}{l}\text { "[A] poor and weak education system creates weak and incompetent generations." } \\
\text { "Without. . . good and suitable training, there is no job." }\end{array}$ \\
\hline
\end{tabular}

The misalignment of youth skills to the job market needs is the main priority among youth in all 17 assessments. The Kenya assessment authors summarized youth perspectives as, "educational vulnerability [is] a condition or a context in which a young person is denied opportunities or abused (financially or emotionally), because they lack the right educational experience, such as education lacking an appropriate balance of practical and theoretical skills." Youth note the importance of overhauling and restructuring the curricula to reflect the skill 
needs of employers. They also note the importance of engaging employers in the curriculum development process to help bridge the gap between education and the market; and ensure that educational preparation is more flexible so that students can adjust to the workforce's ever-changing needs.

The quality of education is also a significant concern in every assessment country. The issues related to quality differ depending on the context. In Latin America, the focus has moved beyond primary education and focuses more on access to secondary education in rural areas, the link between secondary education and the workforce, and combatting gender stereotyping in education. Youth also mention the need for more funding for tertiary education. Across Africa, youth needs are still focused on improving the quality and access to primary and secondary education. Youth note challenges with language policies and the differences between private and public education. While rural youth across all 17 CYSAs face more challenges in completing education, the difference between rural and urban youth in Africa is the starkest. Youth in Armenia and the Kyrgyz Republic noted issues related to gender disparities and discrimination. They also noted many young people complete their education and migrate internationally to find better-paying employment with their skill sets. Quality of education issues tended to affect women in all 17 countries more than their male counterparts and marginalized populations (e.g., students living with disabilities, impoverished youth, and ethnic minorities). The gaps between privileged youth and the vulnerable continue to grow, and educational inequities fuel the disparities.

Youth in these countries face challenges beyond the traditional quality of education issues. In many instances, there are perceptions that only specific jobs are acceptable, and social norms directly impact youth choices related to formal education versus vocational training. Job training and technical and vocational education and training (TVET) programs typically build physical or menial labor skills, which tend to be negatively perceived and linked to lower social status. Many families are ashamed to have their children work in these professions (e.g., plumber, electrician, fisherman). Youth described these less-desirable jobs as "discouraging, illegal, and immoral." Those youth who have dreams of breaking the cycle of poverty by pursuing a formal education appear to have the strongest aversion to these occupations and take extra measures to distance themselves. Structural and institutional barriers continue to impede the formal education system from working directly with the private sector to link education curricula to formal employment at all levels (not just technical and vocational). The most successful education reform programs identified in the assessments are the ones that have taken a systems approach and linked education more closely to businesses and employment. 


\section{Opportunities for Strategic Engagement}

Governments and donors have been investing in education reforms for decades, and youth skill sets have improved over time. However, an analysis of the 17 assessments shows that youth feel more needs to be done, particularly in the agency, contribution, and enabling environments. Table 7 highlights exemplar programs that helped improve education quality and access around the world.

\section{Table 7. Exemplar Programs Building Youth Education and Employability Skills}

\begin{tabular}{|c|c|}
\hline Program & Description \\
\hline Jeune Espoir (Guinea) & $\begin{array}{l}\text { Installs online and local learning management systems for schools and } \\
\text { educational centers; develops digital courses for the primary, middle, and } \\
\text { high school levels; and builds digital courses for studying English, } \\
\text { business, and computers skills. }\end{array}$ \\
\hline $\begin{array}{l}\text { Kenya Youth Employment and Skills } \\
\text { Program (K-YES) }\end{array}$ & $\begin{array}{l}\text { Works with youth ages } 18-35 \text { to develop vocational and/or business skills } \\
\text { for either the formal or informal sectors. The program demonstrates that } \\
\text { combining vocational and business skills training may magnify outcomes } \\
\text { along with linkages to financial services. }\end{array}$ \\
\hline Teach for Madagascar & $\begin{array}{l}\text { Places Malagasy youth as volunteers to develop work experience. } \\
\text { Additionally, the Ministry of Education is building an entrepreneurial major } \\
\text { into secondary education. }\end{array}$ \\
\hline $\begin{array}{l}\text { Empowering Mauritanian Youth } \\
\text { through Education, Leadership, and } \\
\text { Self-Improvement (EMELI) }\end{array}$ & $\begin{array}{l}\text { Uses a holistic approach to youth employability, personal development, } \\
\text { soft skills, and leadership training coupled with the opportunity for civic } \\
\text { engagement and cultural expression through a youth cultural center to } \\
\text { reduce youth's grievances, and, thereby, prevent extremist tendencies. }\end{array}$ \\
\hline ProJoven II (Honduras) & $\begin{array}{l}\text { Includes a central "psychosocial skills" component, which focuses on } \\
\text { active listening, sensitivity, creativity, and conflict resolution. Provides } \\
\text { childcare at the training centers to ensure that having young children does } \\
\text { not become a barrier to professional training. }\end{array}$ \\
\hline
\end{tabular}

While these programs target youth in different countries, they share several characteristics that youth identified as key to building their assets and agency. First, these programs use a variety of delivery platforms to reach youth. Jeune Espoir draws on digital courses, K-YES links vocational and business skills to financial services, and ProJoven II builds strong psychosocial skills and childcare to ensure young parents can continue to study. Second, all five programs strongly link traditional education skills to workplace skill needs. Finally, several programs also bring in strong, soft skill and leadership components that engage youth and help them develop important conflict resolution assets, cultural expression, and listening skills.

\section{What Do Youth Voices Teach Us About Health?}

Whatever the level of education, the wealth, or the will of a person to succeed or reach his goals, without good health everything is doomed to failure.

-Youth, Guinea 
According to the World Health Organization (2021), more than 1.5 million youth and adolescents between the ages of 10 and 24 died in 2019. Causes of death included injuries, violence, self-harm and depression, and maternal conditions. The probability of dying varies significantly by region. Youth and adolescents in sub-Saharan Africa face the highest risks of dying before age 24-in fact, the risk is six times higher than in North America and Europe. Violence, depression and mental health issues, and infectious diseases are among the top 10 causes of death among youth. Complications related to early pregnancy and birthing are the number one cause of death among girls aged 15 to 19 worldwide. "Investments in adolescent health and well-being bring benefits today, for decades to come, and for the next generation" (Patton et al., 2016).

\section{Youth Needs and Priorities}

Despite health being an area of lesser focus across the CYSAs health-related facilitators, barriers and opportunities are essential to youth. Youth needs align with the WHO's risks related to mental and psychological health, family planning, and reproductive health, specifically early pregnancy, each mentioned in eleven assessments. Countries recognize and are actively addressing the need for comprehensive access to family planning and reproductive health services via new family planning policies and education (e.g., Madagascar) or broader health sector reform (e.g., Mauritania). Other countries (e.g., Dominican Republic, Madagascar) have made reproductive health and teen pregnancy key areas of focus for national youth policies and youth-friendly services. In Madagascar, the new Reproductive Health and Family Planning law seeks to improve access to these services. The National Strategy for Peer Education leverages youth spaces to support youth in the healthcare systems via peer education. Mental and psychological health needs have received more attention, increasingly so in assessments done after the start of the COVID-19 pandemic. In the Eastern and Southern Caribbean, healthcare providers have prioritized psychosocial services for victims and perpetrators of violence. Community-based organizations in DRC offer a shining example of incorporating psychosocial counseling into their suite of services by working with communities to address the impact of conflict-related trauma as well as reintegrating individuals who participated in conflict back into society. Creating youth-friendly health spaces that address reproductive and mental health and nutrition are critical areas of advocacy and action. In countries such as Rwanda, youth-friendly centers have improved health service delivery to young populations and serve as an opportunity to address non-health needs related to education and employment.

Access to basic health services (e.g., Guinea) continues to be a challenge, with existing health systems being of low quality and mainly depending on humanitarian assistance programs and 
support from the international development community. Challenges of providing medical supplies and having the necessary equipment to store and transport medicines in Somalia also persist, in addition to concerns about healthcare service quality. Table 8 shares what young people highlighted as key health issues facing them in the countries assessed.

Table 8. Youth Perspectives on Health Challenges

\begin{tabular}{|c|c|}
\hline Country & Youth perspectives noted in the CSYAs \\
\hline DRC & $\begin{array}{l}\text { "People facing physical or mental disabilities face discrimination and can be stigmatized by } \\
\text { their families and communities." }\end{array}$ \\
\hline Dominican Republic & $\begin{array}{l}\text { "Alcohol and drug use is growing among adolescents, and there are very few options for } \\
\text { rehabilitation. Options that exist are either too expensive, of poor quality, or not appropriate } \\
\text { for the additional complexities of adolescent drug use." }\end{array}$ \\
\hline $\begin{array}{l}\text { Eastern and } \\
\text { Southern Caribbean }\end{array}$ & $\begin{array}{l}\text { "Accessing sexual reproductive health services is difficult for both sexes. Males typically do } \\
\text { not want to go see doctors and with females... the legal age for consent is sixteen, but she } \\
\text { cannot access the services until she is eighteen, so there is a two-year gap where some } \\
\text { young girls can contract an STI or HIV but cannot receive services [without a parent or } \\
\text { guardian present]." }\end{array}$ \\
\hline Honduras & $\begin{array}{l}\text { "There are health centers here that provide women with corn and beans during prenatal } \\
\text { visits. Here it is by affinity. If you are not of the right political color, you are not given the } \\
\text { help. If you do not have connections, you do not receive anything." }\end{array}$ \\
\hline Kenya & $\begin{array}{l}\text { Youth talked about psychological health as "a mental state, a stress so debilitating that it } \\
\text { prevents [young people] from making the right choices in life, forcing them to give up trying } \\
\text { to succeed. It can result in a deep depression or self-harm." }\end{array}$ \\
\hline Kyrgyz Republic & $\begin{array}{l}\text { "Tuberculosis is checked in schools and hospitals but if the person is registered nowhere, if } \\
\text { he is living in bazaars, he is not checked. The population is not informed enough."-Youth } \\
\text { Focus Group Participant }\end{array}$ \\
\hline Liberia & $\begin{array}{l}\text { "Teenagers are involved with prostitution because of the lack of (financial) support, and girls } \\
\text { end up getting pregnant." }\end{array}$ \\
\hline Mauritania & $\begin{array}{l}\text { Youth cited "social wounds that never healed" and expressed worry that intergenerational } \\
\text { trauma may be limiting youth potential and impacting levels of empathy. Still, mental health } \\
\text { continues to carry a heavy stigma, with many believing that only "crazy" people would seek } \\
\text { mental health support. }\end{array}$ \\
\hline Rwanda & $\begin{array}{l}\text { "We are not comfortable with health centers services when discussing secret issues because } \\
\text { nurses are from our neighborhood." }\end{array}$ \\
\hline Somalia & "Youth use drugs because they want to get rid of stress and get temporary relief." \\
\hline
\end{tabular}

The lack of youth-friendly health services that address adolescent-specific needs was an issue raised in 10 assessments. Alcohol and substance-use-related issues and limited availability of substance-use treatment and prevention programs are a barrier to improving youth status in half the assessments. Youth cited confidentiality concerns as a barrier and a reason youth avoid seeking care until they have more significant health symptoms or stigma, specifically related to mental health concerns. Females in these countries were the most concerned with improving health and related safety outcomes. In Rwanda, older youth participating in assessment activities prioritized promoting health outcomes. Conversely, in Madagascar and Guinea, stakeholders noted the importance of engaging with parents and teachers to work with very young adolescents on reproductive health education. 


\section{Opportunities for Strategic Engagement}

Governments and donors continue to invest in health programming for youth. However, an analysis of the 17 assessments shows that more needs to be done, particularly around sexual and reproductive health, early pregnancy, substance abuse, and the creation of safe spaces. Table 9 highlights exemplar programs that are targeting improved health outcomes for youth worldwide.

\section{Table 9. Exemplar Programs Targeting Improvements in Youth Health}

\begin{tabular}{|c|c|}
\hline Program & Description \\
\hline $\begin{array}{l}\text { Youth-powered } \\
\text { Ecosystem to Advance } \\
\text { Urban Adolescent Health } \\
\text { and Well-being }\end{array}$ & $\begin{array}{l}\text { Awarded in 2020, this program works with a group of specialized local partners to } \\
\text { establish and strengthen a network of "youth hubs" in the state capitals of Lagos and } \\
\text { Kano in Nigeria. The hubs will provide two million adolescent girls and boys with safe } \\
\text { spaces where they will acquire skills to lead healthier, more productive lives through } \\
\text { counseling on reproductive health, practical information for workforce development, and } \\
\text { fun activities and sports that encourage self-esteem and team building. }\end{array}$ \\
\hline $\begin{array}{l}\text { DREAMS (Determined, } \\
\text { Resilient, Empowered, } \\
\text { AIDS-free, Mentored and } \\
\text { Safe) Partnership (Kenya, } \\
\text { Rwanda, Zambia and } \\
\text { others) }\end{array}$ & $\begin{array}{l}\text { The DREAMS program is a public-private partnership that focuses on reducing rates of } \\
\text { HIV among adolescent girls and young women (AGYW) in the highest HIV burden } \\
\text { countries. The program builds on USAID's decades of experience empowering young } \\
\text { women and advancing gender equality across health, education, and economic growth. } \\
\text { DREAMS mobilizes significant numbers of volunteers to address the structural } \\
\text { inequalities that impact girls' vulnerability to HIV. DREAMS has been implemented in } 15 \\
\text { countries around the world since } 2015 \text {. }\end{array}$ \\
\hline $\begin{array}{l}\text { Support for International } \\
\text { Family Planning } \\
\text { Organizations } 2 \text { (SIFPO2) } \\
\text { (Liberia, Dominican } \\
\text { Republic, Ethiopia, } \\
\text { Zambia, and } 13 \text { other } \\
\text { countries) }\end{array}$ & $\begin{array}{l}\text { SIFPO2 supports family planning services for youth, including mobile outreach, university } \\
\text { campuses, integration with immunization services, and curriculum development. This } \\
\text { youth-focused activity targeted unmarried young people aged } 15-24 \text { and the adults who } \\
\text { influence young unmarried people- primarily parents and, to a lesser extent, teachers, } \\
\text { community and religious leaders, general community health workers, and clinical service } \\
\text { providers. SIFPO2 also trained health providers in the provision of youth-friendly health } \\
\text { services. }\end{array}$ \\
\hline
\end{tabular}

What Do Youth Voices Teach Us about Democracy, Rights, and Governance?

We are usually called by the government official to listen to what they have already decided, and [they] simply consider our participation a decoration. -Youth, Ethiopia

Youth worldwide face many socio-cultural, structural, and institutional challenges as they move from childhood to active citizenship in adulthood. Females face more challenges to meaningful engagement due to family and community norms. Similarly, "youth with disabilities, LGBTI youth, and ethnic or religious minority youth confront additional barriers and formal and informal restrictions to fully exercising their rights" (International Foundation for Electoral Systems, 2016). Now more than ever, it is essential that we, as a society, build democratic values, engage youth in political processes, and create meaningful opportunities for participation. 


\section{Youth Needs and Priorities}

Young people in every country expressed frustration that adults and society writ large did not hear their voices. They also acknowledged that they had few opportunities to develop leadership roles. When focused particularly on civic engagement, the story was mixed. Youth expressed disillusionment with government and disinterest in engaging in politics. They felt exploited by politicians or ignored by a corrupt, ill-performing government, leading young people to feel excluded from politics and decision-making tables. In contexts where conflict was or has been more prevalent, or the country's political system was undergoing active change or resistance (i.e., DRC, Ethiopia, and Somalia), the youth wanted to be more engaged and contribute civically. Table 10 presents youth voices that reflect the dissatisfaction around civic engagement.

\section{Table 10. Youth Perspectives on Civic Engagement}

\begin{tabular}{|c|c|}
\hline Country & Youth perspectives noted in the CSYAs \\
\hline Armenia & $\begin{array}{l}\text { Young women are seemingly engaged [in civic and political life] more than young men } \\
\text { because it provides an avenue for socialization independent of the family in parallel with the } \\
\text { pursuit of benefits for the community. }\end{array}$ \\
\hline Dominican Republic & $\begin{array}{l}\text { Youth are very motivated to participate in movements promoting human rights, social activism, } \\
\text { and racial and ethnicity equality. Youth are interested in environmental activism and are often } \\
\text { inspired by what they read on social media about global movements for climate change, } \\
\text { reduction of pollution, water conservation, }\end{array}$ \\
\hline Ethiopia & $\begin{array}{l}\text { "The government usually tell us 'these are your [government-affiliated youth associations] } \\
\text { leaders' but we don't know how they are elected and even where these youth leaders came } \\
\text { from." }\end{array}$ \\
\hline Honduras & $\begin{array}{l}\text { Social and political exclusion are also a key source of youth dissatisfaction. Political polarization } \\
\text { runs deep, and the sense of corruption in local institutions causes many young people to feel } \\
\text { shut out of political participation and decision-making spaces. }\end{array}$ \\
\hline Liberia & $\begin{array}{l}\text { "There is nothing like youth activities for keeping us busy after school and work. We are totally } \\
\text { lacking a recreation center in this community which is important to our living." }\end{array}$ \\
\hline Kenya & $\begin{array}{l}\text { Young people with a lower socioeconomic status, youth living with disabilities, and young } \\
\text { women are not heard. }\end{array}$ \\
\hline Kyrgyz Republic & $\begin{array}{l}\text { Youth described themselves as disinterested in joining political parties or becoming actively } \\
\text { involved in politics, due to their perceptions of corruption and lack of trust in political systems. }\end{array}$ \\
\hline Rwanda & $\begin{array}{l}\text { Youth felt more motivated to participate in community activities when they have greater } \\
\text { leadership roles ... [but noted] parents do not encourage youth to get involved in civic } \\
\text { society because of an emphasis on household work or income-generating activities. }\end{array}$ \\
\hline Somalia & $\begin{array}{l}\text { Youth see tribalism and control of decision making by elders as barriers to participation, even } \\
\text { in areas where youth are welcome in decision-making bodies. }\end{array}$ \\
\hline
\end{tabular}

Peace and security affect youth civic engagement and participation. Perceptions around peace or security varied significantly based on the development context, with those in conflict or postconflict environments focused on security considering violent extremism and societal instability. In contrast, those afflicted by high crime rates or gangs focused on personal safety in light of violence. Table 11 gives voice to youth safety concerns. 
Table 11. Youth-Identified Safety, Security, and Violence Concerns

\begin{tabular}{|c|c|}
\hline Country & Youth perspectives noted in the CSYAs \\
\hline DRC & $\begin{array}{l}\text { [When] youth are largely disenfranchised and socio-economically distressed with little to no relief coming } \\
\text { from the government, youth become vulnerable to the manipulation and coercion of political leaders. }\end{array}$ \\
\hline $\begin{array}{l}\text { Dominican } \\
\text { Republic }\end{array}$ & $\begin{array}{l}\text { Noted that verbal and psychological violence, perpetrated by family members, police, and other } \\
\text { authorities against youth, is common, particularly for young people living in poverty. }\end{array}$ \\
\hline Ethiopia & $\begin{array}{l}\text { "Suicide is one way to escape the abuses and restrictions we face and the hopelessness we regularly } \\
\text { feel." -Youth Focus Group Participant }\end{array}$ \\
\hline Honduras & $\begin{array}{l}\text { Many youth do not view domestic violence as violence; they see it as a normal part of family life. } \\
\text { In the absence of consistent work, school, or recreation, some start to drink, some get involved in petty } \\
\text { crime, and others get entangled in even more serious crimes, such as drug trafficking, assault, and } \\
\text { extortion. }\end{array}$ \\
\hline Liberia & "Our leaders here do nothing for us, we protect our own community." -Youth Focus Group Participant \\
\hline Mauritania & $\begin{array}{l}\text { "Her family won't support her. They won't stand with her as a victim of rape. They will consider that she } \\
\text { has lost her honor, which complicates things. Society, friends, family-instead of supporting the victim, } \\
\text { they make her suffer psychologically. They consider the girl to be the guilty one." -Youth Focus Group } \\
\text { Participant }\end{array}$ \\
\hline Somalia & $\begin{array}{l}\text { "Al-Shabab recruiters may be the only people who approach and "value" youth." -Youth Focus Group } \\
\text { Participant } \\
\text { "Youth would stop looking for opportunities outside the country if the safety and security of the country } \\
\text { was improved. They would stay within the community to help make it a better place." -Youth Focus } \\
\text { Group Participant }\end{array}$ \\
\hline
\end{tabular}

Youth in DRC, Ethiopia, Liberia, Mauritania, and Somalia expressed concerns about extremism or societal instability. Reasons for conflict vary, but the youth in these contexts expressed a strong desire to engage in their society. As the DRC assessment noted, that desire can be capitalized "to strengthen the foundation for peaceful transformation in which youth are active, positive contributors to social, economic, and political life." Youth noted opportunities in the creation of safe spaces and outlets for self-expression. These spaces enable emotional growth and confidence building, foster communication skills, and teach conflict resolution.

Simultaneously, some assessments noted the limited capacity and programming of civil society organizations to address drivers of instability and its impact on young people.

\section{Opportunities for strategic engagement}

There is an opportunity to engage youth more strategically and strengthen capacity in the design and delivery of services, policies, and programs in countries like the Dominican Republic, Guinea, and Madagascar because of a growing and connected network of youth associations, youth-led NGOs, and young leaders. Youth also engaged in volunteerism and other forms of self-organizing, with Rwanda's Umuganda being a bright example of creating a practice of community engagement using existing structures.

Assessments highlighted the importance of building trust between young people, public institutions, and other community stakeholders. In most countries, youth discussed how transactional sex, rape, gender-based violence, sexual extortion in schools and workplaces, and 
migration threaten women's safety. Across contexts, young men acknowledged the challenge young women faced and, in many cases, wanted to be part of changing that reality. Table 12 highlights exemplar programs that aim to promote youth participation worldwide.

Table 12. Exemplar Programs Building Youth Civic Engagement and Participation

\begin{tabular}{|c|c|}
\hline Program & Description \\
\hline $\begin{array}{l}\text { Liberia } \\
\text { Media } \\
\text { Development } \\
\text { (LMD) }\end{array}$ & $\begin{array}{l}\text { LMD aims to increase Liberian citizens' access to independent and reliable information and } \\
\text { empowerment through a sustainable, quality, more pluralistic, and freer media. One of the five } \\
\text { objectives is to achieve a "plurality of voices" in media, with an emphasis on youth as well as women } \\
\text { and rural concerns. Several interventions engage youth as leaders and activity participants; skills } \\
\text { training is offered to address skills deficiencies among youth; and mentoring is offered to young } \\
\text { women. }\end{array}$ \\
\hline $\begin{array}{l}\text { Prevention } \\
\text { and } \\
\text { Mitigation of } \\
\text { SGBV in } \\
\text { North and } \\
\text { South Kivu } \\
\text { (DRC) }\end{array}$ & $\begin{array}{l}\text { This project, implemented by the IRC, piloted and evaluated innovative approaches to prevent sexual } \\
\text { and gender-based violence (SGBV) and provided tailored services to SGBV survivors. Among other } \\
\text { activities, it piloted innovative support to address the needs of children and adolescent survivors, } \\
\text { piloted activities designed to target both men and women and empower men as agents of change, } \\
\text { and contributed to increasing the capacity of local NGOs and CBOs intervening in the field of SGBV. }\end{array}$ \\
\hline $\begin{array}{l}\text { Transition } \\
\text { Initiatives } \\
\text { for } \\
\text { Stabilization } \\
\text { Plus (TIS+) } \\
\text { activity } \\
\text { (Somalia) }\end{array}$ & $\begin{array}{l}\text { TIS+ works with multiple levels of government supporting inclusive participation of stakeholder } \\
\text { groups in community decision making and encouraging shared asset management between citizens } \\
\text { and the government. TIS+ uses gender equality and social inclusion (GESI) and sports for } \\
\text { development and peace (SDP) approaches to engage people with disabilities, women, and youth. } \\
\text { Sports are a hook attracting at-risk youth to reduce their engagement in violent extremism and offer } \\
\text { disabled youth the ability to participate as referees and coaches. TIS+ finds that robust and regular } \\
\text { analysis of political-economic dynamics is critical for intervention success. It provides micro-level } \\
\text { understanding and mitigates security-related challenges. }\end{array}$ \\
\hline
\end{tabular}

\section{What Can Youth Program Implementers, Governments, and Donors Learn From These Assessments That Contribute to Addressing the Ongoing Challenges Youth Face Worldwide?}

The results of the assessments aimed to strengthen and inform USAID strategies, design, and youth programming as well as collaboration opportunities with donors, governments, and the private sector. The discussion that follows provides key programmatic, research, and policy implications based on the findings from the youth assessments and recommendations and programming options shared in the various assessment reports.

Taking a PYD approach requires intentional youth inclusion and a cross-sector focus on programming, including the different assets, opportunities, and barriers that youth face within a given system. The PYD framework, with its four domains, provides a lens for considering how youth programming helps young people make a successful transition to adulthood (Catalano et al., 2019). The four domains are defined and applied to programming as follows:

- Assets: Youth have the necessary resources and skills to achieve desired outcomes. Activities that target only the highest educated youth, or those with pre-existing skills 
reinforce unintentional biases against the large proportion of youth. Programming should incorporate skills development through direct implementation or coordination with other initiatives.

- Agency: Youth can employ their assets and aspirations to make [and act upon] their own decisions. This application requires that programs engage with families, adults, leaders, institutions, and policies to reduce any obstacles that prevent youth from participating and applying their assets.

- Contribution: Youth are encouraged, recognized, and able to be involved in and lead through various channels as a source of change. Meaningful participation requires dedicated time and funding to ensure that youth lead and contribute to design, implementation, monitoring, and evaluation.

- Enabling Environment: Youth are surrounded by an enabling environment that maximizes their assets, agency, access to services and opportunities, and ability to avoid risks while promoting their social and emotional competence to thrive. Enabling environments can be supported by developing high-quality, safe spaces, building relationships, and addressing norms, expectations, perceptions, and access to youthfriendly and integrated services. Creating more supportive environments require improved coordination, better integration of service focused on safe, gender-responsive programming. Programming needs to engage parents, elders, and peers as partners, given their importance to youth development.

\section{Implications for Youth Program Implementers}

Three consistent recommendations across the assessments are (a) build capacity around adolescent and positive youth development, (b) be intentional about focusing on and engaging with youth, and (c) ensure programming is holistic and cross-sectoral to achieve more substantial outcomes. While Table 13 provides a flavor for sector-specific approaches to programming using a PYD framework. The programming approaches outlined are not exhaustive. Instead, they highlight recommendations articulated in various assessment documents and spur readers to consider how sector-specific approaches are conceived or strengthened when applied across the PYD domains. The critical programming approaches aim to address what youth articulated as priorities, such as improved livelihood opportunities, more practical education, addressing key health concerns, opportunities for more voice in society, and greater safety and security. At the heart of these approaches are ensuring youth have the requisite resources, supportive environment, and opportunities to contribute to shaping the systems that affect them. 
Table 13. Programming Approaches Addressing Sector-Specific Findings Using a PYD Framework

\begin{tabular}{|c|c|c|c|c|}
\hline \multirow[t]{2}{*}{ Approaches } & \multicolumn{4}{|c|}{ PYD Framework } \\
\hline & Assets & Agency & Contribution & Enabling environment \\
\hline \multicolumn{5}{|c|}{ Economic development and livelihoods } \\
\hline $\begin{array}{l}\text { Create self- } \\
\text { employment } \\
\text { opportunities }\end{array}$ & $\begin{array}{l}\text { Enable financial literacy, } \\
\text { financial resources, credit line, } \\
\text { access to grants, and } \\
\text { incubators/hubs. }\end{array}$ & $\begin{array}{l}\text { Help youth understand where } \\
\text { to go to gather information on } \\
\text { business start-ups and provide } \\
\text { mentors/guides to support } \\
\text { them. }\end{array}$ & $\begin{array}{l}\text { Create incubators that allow } \\
\text { youth to share experiences and } \\
\text { help their peers learn. }\end{array}$ & $\begin{array}{l}\text { Reform systems to facilitate youth } \\
\text { access to credit and business } \\
\text { support. }\end{array}$ \\
\hline $\begin{array}{l}\text { Develop effective } \\
\text { Labor Market } \\
\text { Information (LMI) } \\
\text { systems }\end{array}$ & $\begin{array}{l}\text { Train youth to use LMI systems } \\
\text { to research employment and } \\
\text { find jobs. }\end{array}$ & $\begin{array}{l}\text { Create transparency so the } \\
\text { application process is fair, and } \\
\text { youth perceive using LMI } \\
\text { systems helps them make } \\
\text { decisions. }\end{array}$ & $\begin{array}{l}\text { Ensure youth can contribute to } \\
\text { posting information in LMI } \\
\text { systems. }\end{array}$ & $\begin{array}{l}\text { Conduct seasonal market } \\
\text { assessments. } \\
\text { Build government capacity to design } \\
\text { and maintain LMI systems in a } \\
\text { timely manner. }\end{array}$ \\
\hline $\begin{array}{l}\text { Engage the private } \\
\text { sector in education } \\
\text { and transition to the } \\
\text { workforce }\end{array}$ & $\begin{array}{l}\text { Engage the private sector to } \\
\text { build the skills youth need for } \\
\text { different types of employment. }\end{array}$ & $\begin{array}{l}\text { Offer counseling, advising, and } \\
\text { support for youth to make } \\
\text { decisions. }\end{array}$ & $\begin{array}{l}\text { Engage youth to serve as } \\
\text { advisors and counselors to peers } \\
\text { as they gain experience } \\
\text { (programs should employ youth } \\
\text { as such). }\end{array}$ & $\begin{array}{l}\text { Provide incentives to support public- } \\
\text { private partnerships and create a } \\
\text { supportive environment that allows } \\
\text { teachers and the private sector to } \\
\text { work together. }\end{array}$ \\
\hline $\begin{array}{l}\text { Realign school-to- } \\
\text { work skills }\end{array}$ & $\begin{array}{l}\text { Identify any gaps within the } \\
\text { skills development chain, } \\
\text { weaknesses, barriers, and/or } \\
\text { limitations for young people, } \\
\text { and integrate hands-on, } \\
\text { practical training, } \\
\text { apprenticeships, and } \\
\text { internships throughout all levels } \\
\text { of education (i.e., primary, } \\
\text { secondary, and tertiary). }\end{array}$ & $\begin{array}{l}\text { Link youth to employment } \\
\text { experiences across multiple } \\
\text { sectors so they can understand } \\
\text { how to use assets and learn } \\
\text { decision-making skills. }\end{array}$ & $\begin{array}{l}\text { Form youth-led school councils } \\
\text { to advocate for appropriate skills } \\
\text { and connect to the private } \\
\text { sector. }\end{array}$ & $\begin{array}{l}\text { Advocate for the Ministry of } \\
\text { Education to engage private sector } \\
\text { and apply best practices to make } \\
\text { private-public partnership work. }\end{array}$ \\
\hline $\begin{array}{l}\text { Engage youth in } \\
\text { solutions }\end{array}$ & $\begin{array}{l}\text { Build youth skills in critical } \\
\text { thinking, decision making, and } \\
\text { communication. }\end{array}$ & $\begin{array}{l}\text { Design education programs to } \\
\text { build confidence, decision } \\
\text { making, and perseverance skills } \\
\text { in youth. }\end{array}$ & $\begin{array}{l}\text { Engage youth in civic } \\
\text { participation and community } \\
\text { development activities such as } \\
\text { school councils and local } \\
\text { community organizations, so } \\
\text { they can contribute to decision- } \\
\text { making processes. }\end{array}$ & $\begin{array}{l}\text { Invest in strengthening the capacity } \\
\text { of government staff and } \\
\text { stakeholders to engage youth as } \\
\text { effective partners in decision } \\
\text { making. }\end{array}$ \\
\hline Rebrand agriculture & $\begin{array}{l}\text { Encourage youth to see } \\
\text { agriculture as a viable } \\
\text { employment option and help } \\
\text { them acquire technical and } \\
\text { business skills to successfully } \\
\text { operate a farm. }\end{array}$ & $\begin{array}{l}\text { Create youth-led cooperatives } \\
\text { and incubators as well as } \\
\text { engage them in peer } \\
\text { education. }\end{array}$ & $\begin{array}{l}\text { Encourage youth-led agri- } \\
\text { businesses to recruit other youth } \\
\text { into sector. }\end{array}$ & $\begin{array}{l}\text { Conduct seasonal market } \\
\text { assessments. } \\
\text { Undertake behavior-change } \\
\text { campaigns. }\end{array}$ \\
\hline
\end{tabular}


Table 13. (continued)

\begin{tabular}{|c|c|c|c|c|}
\hline \multirow[t]{2}{*}{ Approaches } & \multicolumn{4}{|c|}{ PYD Framework } \\
\hline & Assets & Agency & Contribution & Enabling environment \\
\hline \multicolumn{5}{|c|}{ Education } \\
\hline $\begin{array}{l}\text { Focus on accelerated } \\
\text { education programs } \\
\text { for marginalized youth }\end{array}$ & $\begin{array}{l}\text { Target out-of-school youth to } \\
\text { not only improve foundational } \\
\text { skills, but also gain specific } \\
\text { workforce-related skills, such as } \\
\text { business administration, } \\
\text { leadership, and sector-specific } \\
\text { technical skills. }\end{array}$ & $\begin{array}{l}\text { Engage program alumni to help } \\
\text { give courses in the program } \\
\text { and mentor future students. }\end{array}$ & $\begin{array}{l}\text { Promote youth-led formation of } \\
\text { public-private partnerships to } \\
\text { continue supporting other young } \\
\text { people and serve as mentors } \\
\text { and counselors. }\end{array}$ & $\begin{array}{l}\text { Enable accelerated programs } \\
\text { through donors, government, and } \\
\text { the private-sector collaborations, } \\
\text { where donors provide initial seed } \\
\text { funding, government provide } \\
\text { ongoing support, and the private } \\
\text { sector helps design curriculum and } \\
\text { mentors youth. }\end{array}$ \\
\hline Re-envision education & $\begin{array}{l}\text { Envision schools as "workforce } \\
\text { hubs" directly linked to both } \\
\text { public and private employment } \\
\text { sectors, where students not } \\
\text { only gain foundational skills in } \\
\text { math, reading, and science, but } \\
\text { also learn specific workforce } \\
\text { skills in a practical, applicable } \\
\text { manner. }\end{array}$ & $\begin{array}{l}\text { Empower youth to own their } \\
\text { education and connect it with } \\
\text { their livelihood aspirations and } \\
\text { desired outcomes. }\end{array}$ & $\begin{array}{l}\text { Engage youth in revisioning, } \\
\text { articulating, and designing what } \\
\text { they need from schools to } \\
\text { achieve a livelihood. }\end{array}$ & $\begin{array}{l}\text { Enable school re-envisioning } \\
\text { through donors, government, and } \\
\text { the private-sector collaborations, } \\
\text { where donors provide initial seed } \\
\text { funding, government provides } \\
\text { ongoing support (e.g., teacher } \\
\text { training for the new schools, } \\
\text { equipment to link to the labor-force } \\
\text { training), and the private sector } \\
\text { helps design curriculum, provides } \\
\text { resources to re-equip schools, offer } \\
\text { teaches courses related to their } \\
\text { sector, and mentors youth. }\end{array}$ \\
\hline $\begin{array}{l}\text { Strengthen TVET } \\
\text { institutions }\end{array}$ & $\begin{array}{l}\text { Provide youth with market- } \\
\text { demanded technical skills in } \\
\text { specific work-related areas. }\end{array}$ & $\begin{array}{l}\text { Promote pride in TVET } \\
\text { education skills and degrees to } \\
\text { foster self-esteem. }\end{array}$ & $\begin{array}{l}\text { Promote youth who successfully } \\
\text { complete TVET, help them find } \\
\text { good employment, and } \\
\text { encourage them to serve as } \\
\text { advocates for the TVET } \\
\text { pathway. }\end{array}$ & $\begin{array}{l}\text { Reform and upgrade the TVET } \\
\text { system (e.g., stronger linkages to all } \\
\text { levels of employment) and develop } \\
\text { behavior-change campaigns focused } \\
\text { on promoting TVET as a viable } \\
\text { pathway to employment. }\end{array}$ \\
\hline $\begin{array}{l}\text { Create public-private } \\
\text { partnerships }\end{array}$ & $\begin{array}{l}\text { Engage in public-private } \\
\text { partnerships that help youth } \\
\text { acquire the technical skills they } \\
\text { need to enter the workforce. }\end{array}$ & $\begin{array}{l}\text { Provide internships, } \\
\text { apprenticeships, and other } \\
\text { opportunities for youth to apply } \\
\text { their technical skills. }\end{array}$ & $\begin{array}{l}\text { Engage youth in identifying } \\
\text { desired partnerships and } \\
\text { structuring them. }\end{array}$ & $\begin{array}{l}\text { Develop public-private partnership } \\
\text { that help create an enabling } \\
\text { environment by providing technical } \\
\text { expertise and financial resources to } \\
\text { improve education and TVET } \\
\text { systems for youth as well as } \\
\text { mentoring. }\end{array}$ \\
\hline
\end{tabular}


Table 13. (continued)

\begin{tabular}{|c|c|c|c|c|}
\hline \multirow[t]{2}{*}{ Approaches } & \multicolumn{4}{|c|}{ PYD Framework } \\
\hline & Assets & Agency & Contribution & Enabling environment \\
\hline \multicolumn{5}{|c|}{ Health } \\
\hline $\begin{array}{l}\text { Support access to } \\
\text { basic health services }\end{array}$ & $\begin{array}{l}\text { Include health and wellness } \\
\text { training and services (e.g., } \\
\text { WASH, HIV/AIDS curricula) as } \\
\text { part of in school and out of } \\
\text { school programming. } \\
\text { Promote fitness, nutrition } \\
\text { education, and well-being } \\
\text { strategies. }\end{array}$ & $\begin{array}{l}\text { Empower youth as agents of } \\
\text { change in social and behavioral } \\
\text { change campaigns focused on } \\
\text { health topics of youth interest. }\end{array}$ & $\begin{array}{l}\text { Model youth efforts during Ebola } \\
\text { campaigns in West Africa to } \\
\text { build trust with community } \\
\text { leaders. }\end{array}$ & $\begin{array}{l}\text { Partner with community members } \\
\text { and services in providing youth } \\
\text { health programming that are } \\
\text { affordable and adapted to suit youth } \\
\text { needs. }\end{array}$ \\
\hline $\begin{array}{l}\text { Address substance } \\
\text { abuse }\end{array}$ & $\begin{array}{l}\text { Launch anti-drug campaigns in } \\
\text { schools, include anti-drug } \\
\text { awareness and messaging in } \\
\text { curricula. }\end{array}$ & $\begin{array}{l}\text { Increase youth resilience to } \\
\text { influences of drugs and alcohol } \\
\text { through educational } \\
\text { campaigns, positive peer } \\
\text { groups, and safe spaces for } \\
\text { creative outlets. }\end{array}$ & $\begin{array}{l}\text { Engage youth to research } \\
\text { substance abuse to understand } \\
\text { prevalence, behaviors, and risk } \\
\text { factors. }\end{array}$ & $\begin{array}{l}\text { Launch social media campaigns to } \\
\text { combat alcohol and drug abuse. } \\
\text { Establish rehabilitation programs to } \\
\text { help youth overcome addiction. } \\
\text { Engage families, communities, and } \\
\text { faith-based organizations in the } \\
\text { response strategy. }\end{array}$ \\
\hline $\begin{array}{l}\text { Increase youth use of } \\
\text { reproductive health } \\
\text { services }\end{array}$ & $\begin{array}{l}\text { Increase youth reproductive } \\
\text { health awareness through } \\
\text { behavior-change- } \\
\text { communication interventions } \\
\text { that link healthy behaviors with } \\
\text { economic opportunity. } \\
\text { Provide reproductive health } \\
\text { education that addresses male } \\
\text { roles in teenage pregnancy and } \\
\text { GBV. }\end{array}$ & $\begin{array}{l}\text { Provide youth-friendly } \\
\text { reproductive health services } \\
\text { that include counseling and } \\
\text { advice. }\end{array}$ & $\begin{array}{l}\text { Enlist youth to lead outreach } \\
\text { campaigns and media on } \\
\text { reproductive health themes. }\end{array}$ & $\begin{array}{l}\text { Train/retrain health care personnel } \\
\text { on modern contraceptive methods. }\end{array}$ \\
\hline $\begin{array}{l}\text { Provide holistic } \\
\text { mental health and } \\
\text { psychosocial support }\end{array}$ & $\begin{array}{l}\text { Address the psychosocial } \\
\text { effects of the COVID-19 } \\
\text { pandemic on the mental health } \\
\text { of youth, including the } \\
\text { consequences of social isolation } \\
\text { and increased economic } \\
\text { distress. }\end{array}$ & $\begin{array}{l}\text { Support protective factors for } \\
\text { young people that include } \\
\text { anger management, impulse } \\
\text { and emotion control, a belief in } \\
\text { one's ability to achieve, and } \\
\text { cognitive awareness. }\end{array}$ & $\begin{array}{l}\text { Establish youth-led and peer- } \\
\text { facilitated safe spaces for } \\
\text { recreation, creativity, } \\
\text { socialization, and engagement. }\end{array}$ & $\begin{array}{l}\text { Reduce stigma so youth will seek } \\
\text { services. } \\
\text { Focus awareness campaigns on } \\
\text { suicide prevention and support. }\end{array}$ \\
\hline
\end{tabular}


Table 13. (continued)

\begin{tabular}{|c|c|c|c|c|}
\hline \multirow[t]{2}{*}{ Approaches } & \multicolumn{4}{|c|}{ PYD Framework } \\
\hline & Assets & Agency & Contribution & Enabling environment \\
\hline \multicolumn{5}{|c|}{ Youth participation and civic engagement } \\
\hline $\begin{array}{l}\text { Building youth } \\
\text { capacity for civic } \\
\text { engagement }\end{array}$ & $\begin{array}{l}\text { Equip young people with } \\
\text { advocacy, leadership, civic, and } \\
\text { peacebuilding skills. }\end{array}$ & $\begin{array}{l}\text { Facilitate positive relationships } \\
\text { and perceptions with adults in } \\
\text { their lives and communities } \\
\text { that will create a space for } \\
\text { youth voice. }\end{array}$ & $\begin{array}{l}\text { Nurture the creation of youth-led } \\
\text { community projects or service- } \\
\text { learning models that also } \\
\text { engage parents, elders, } \\
\text { government officials, and } \\
\text { community leaders. }\end{array}$ & $\begin{array}{l}\text { Foster normative changes that aim } \\
\text { to combat age discrimination and } \\
\text { promote positive examples of youth } \\
\text { engagement. }\end{array}$ \\
\hline $\begin{array}{l}\text { Strengthen youth civil } \\
\text { society organization } \\
\text { (CSOs) }\end{array}$ & $\begin{array}{l}\text { Provide youth CSOs with } \\
\text { extensive training, starting with } \\
\text { an organizational capacity } \\
\text { assessment (such as YPAT, } \\
\text { (FHI 360, 2019)). }\end{array}$ & $\begin{array}{l}\text { Promote reflection and broad } \\
\text { perspectives from youth in } \\
\text { generating areas and plans for } \\
\text { improvement. }\end{array}$ & $\begin{array}{l}\text { Develop youth volunteerism } \\
\text { including establishing and } \\
\text { maintaining volunteer } \\
\text { management structures. }\end{array}$ & $\begin{array}{l}\text { Foster trust, relationships and } \\
\text { synergies between youth CSOs, } \\
\text { community services, and local } \\
\text { government. }\end{array}$ \\
\hline $\begin{array}{l}\text { Encourage meaningful } \\
\text { engagement and } \\
\text { leadership in local and } \\
\text { national government } \\
\text { institutions that can } \\
\text { support demand- } \\
\text { driven service } \\
\text { provision }\end{array}$ & $\begin{array}{l}\text { Model programs like the Young } \\
\text { African Leaders Initiative or } \\
\text { other regional equivalents } \\
\text { (e.g., Young Southeast Asian } \\
\text { Leaders Initiative) to build } \\
\text { assets for promoting civic } \\
\text { engagement and leadership. }\end{array}$ & $\begin{array}{l}\text { Raise young people as role } \\
\text { models and leaders in } \\
\text { government. }\end{array}$ & $\begin{array}{l}\text { Expand leadership opportunities } \\
\text { for youth focused on human } \\
\text { rights, democracy, governance, } \\
\text { such as youth advisory councils } \\
\text { and community score cards. }\end{array}$ & $\begin{array}{l}\text { Promote accountability and build } \\
\text { trust between young people and } \\
\text { their institutions using common } \\
\text { platforms: social media, radio, and } \\
\text { TV. } \\
\text { Strengthen the judicial and law } \\
\text { enforcement systems. }\end{array}$ \\
\hline
\end{tabular}


Table 13. (continued)

\begin{tabular}{|c|c|c|c|c|}
\hline \multirow[t]{2}{*}{ Approaches } & \multicolumn{4}{|c|}{ PYD Framework } \\
\hline & Assets & Agency & Contribution & Enabling environment \\
\hline \multicolumn{5}{|c|}{ Safety and security } \\
\hline $\begin{array}{l}\text { Apply conflict- } \\
\text { sensitive approaches } \\
\text { in fragile } \\
\text { environments }\end{array}$ & $\begin{array}{l}\text { Use conflict sensitivity in the } \\
\text { selection of participants. }\end{array}$ & $\begin{array}{l}\text { Ensure inclusion using } \\
\text { principles of "do no harm" and } \\
\text { "do nothing about them } \\
\text { without them." }\end{array}$ & $\begin{array}{l}\text { Extend outreach and } \\
\text { engagement using conflict } \\
\text { sensitivity to target not only } \\
\text { youth but also their parents, } \\
\text { families, and community leaders } \\
\text { as well as the private sector. }\end{array}$ & $\begin{array}{l}\text { Use conflict sensitivity in the } \\
\text { selection of local and private sector } \\
\text { partners. } \\
\text { Create flexible, adaptive } \\
\text { management systems to respond to } \\
\text { the complex and dynamic systems } \\
\text { in which youth programs operate. }\end{array}$ \\
\hline $\begin{array}{l}\text { Continue work to } \\
\text { reduce high crime } \\
\text { rates, lower homicide } \\
\text { rates, and combat } \\
\text { illegal drug trade }\end{array}$ & $\begin{array}{l}\text { Invest in awareness raising } \\
\text { campaigns on the societal harm } \\
\text { of crime and provide alternative } \\
\text { narratives and options. }\end{array}$ & $\begin{array}{l}\text { Nurture youth agency to } \\
\text { advocate and facilitate } \\
\text { normative change. }\end{array}$ & $\begin{array}{l}\text { Provide safe spaces for youth to } \\
\text { positively contribute, while } \\
\text { gaining alternative skills and } \\
\text { building a sense of belonging. }\end{array}$ & $\begin{array}{l}\text { Use public health intervention } \\
\text { approaches and media campaigns. } \\
\text { Facilitate freedom of movement and } \\
\text { access to services and secure } \\
\text { unsafe gang or extremist controlled } \\
\text { areas. }\end{array}$ \\
\hline $\begin{array}{l}\text { Address gender-based } \\
\text { violence and } \\
\text { marginalization abuse }\end{array}$ & $\begin{array}{l}\text { Develop targeted programming } \\
\text { and sensitivity training. }\end{array}$ & $\begin{array}{l}\text { Elevate the voice of women } \\
\text { and marginalized groups. }\end{array}$ & $\begin{array}{l}\text { Engage boys and men in } \\
\text { addressing gender-based } \\
\text { violence and empower them to } \\
\text { be agents of change. }\end{array}$ & $\begin{array}{l}\text { Create media campaigns that } \\
\text { apprises potential victims of their } \\
\text { rights and potential abusers of the } \\
\text { consequences and stigmatization of } \\
\text { such behavior. }\end{array}$ \\
\hline $\begin{array}{l}\text { Create physical and } \\
\text { virtual safe spaces }\end{array}$ & $\begin{array}{l}\text { Train youth, particularly } \\
\text { women, about online safety. } \\
\text { Consider safe spaces spanning } \\
\text { interests and social activities } \\
\text { such as peace clubs, choirs, } \\
\text { sports, community radio, } \\
\text { community-based security } \\
\text { groups, reforestation, and } \\
\text { cultural activities. }\end{array}$ & $\begin{array}{l}\text { Empower youth to create } \\
\text { spaces in their vision, aligned } \\
\text { with their needs as designers } \\
\text { and implementers. }\end{array}$ & $\begin{array}{l}\text { Provide leadership opportunities } \\
\text { for youth, as peer educators or } \\
\text { group leaders. }\end{array}$ & $\begin{array}{l}\text { Transform attitudes and create } \\
\text { normative change related to gender } \\
\text { and ethnic affiliation discrimination. }\end{array}$ \\
\hline
\end{tabular}




\section{Implications for USAID and Other Donors}

Beyond the sector-specific implications of the CSYA findings, there are the broader implications for USAID and other donor investments in youth development. The YouthPower youth assessment experience sheds light on several areas for attention, in the design of youth activities and projects as well as within donor's internal decision-making structures that affect youth programming.

Rooted in USAID's Youth in Development Policy's emphasis on cross-sectoral youth programming, most youth assessments have recommended USAID missions apply a crosssectoral lens to funding and design of youth programming, thereby shaping holistic activities that address youth's multi-sectoral needs. Nonetheless, missions still struggle with how to do this within the realities of their operating norms and structures. There are difficulties for USAID mission staff to collaborate across their technical sector teams and leverage funding to design cross-sectoral activities due to a range of challenges (i.e., earmarks, requirements for how funds should be spent, and competition over funding). Despite the consistent push for crosssectoral programming, missions need to adapt the way they work to support this type of programming. Mission leadership is a primary factor that has proven instrumental for fostering cross-sectoral collaboration and incentivizing staff to support this way of doing business.

Another strategy is to continue raising awareness among USAID mission staff and donors writ large of the value of positive youth development and how to apply this approach to their programs and activities. While it is true that youth assessments are highly effective in sparking awareness within missions of the needs and opportunities of young people and encouraging the view that youth are assets in development, there remains more work to be done. It is now fairly common to include the phrase "youth-led solutions" in activity designs and goal statements, but the actual shift in power dynamics to where youth are entrusted with responsibility and resources to lead the programming is still pretty rare in USAID and donor-funded youth programming. Moreover, trust-on the part of donors toward youth and among youth toward donors-is still a work in progress. These behaviors and mindsets take time to impact and are not achieved based on only a report or presentation. Donor-funded youth programs also risk creating disincentives for local stakeholders to assume responsibility for and a commitment to youth development in their countries. USAID and other donors should rethink their roles in youth programming, switching from the funding of innovations in service delivery to a facilitator's approach that encourages locally-driven youth development solutions in coordination with other donors and country stakeholders. Two ways donors can re-shape their youth 
programming are through developing more direct partnerships with youth-led organizations and establishing more substantive mechanisms to engage youth leaders and stakeholders in decision making. Several youth assessments have recommended creating Youth Advisory Committees. There are other promising signs of progress among donors in this regard. The USAID/Washington-funded activity, Youth Exce/ is wholly focused on supporting under-utilized youth-led and youth-serving organizations to lead implementation research around PYD programming. Mastercard Foundation recently created its own strategy devoted to strengthening youth engagement in its programming, and the Plan International (2021) developed the "Youth Voices in Youth Employment" Roadmap commissioned by the Citi Foundation in collaboration with the Youth Employment Funders Group to guide international donors on how to strengthen youth engagement in their youth employment programming.

Additionally, the experience from the CSYAs has implications for the content of donor-funded youth programs. Again, numerous youth assessments have recommended fostering "enabling environments" for youth. As we have discussed above, the CSYAs' comprehensive analyses of the youth landscape have identified the many interwoven issues that affect youth's ability to positively contribute to their own development, and yet, there have not been many youth activities focused on addressing systemic problems, policies, or norms resulting from these CSYAs. Donor-funded and particularly USAID youth programs, still tend to be structured around shorter time frames and easier-to-measure outputs, such as number of youth trained, which make focusing on longer-term outcomes such as policy reform or attitudinal changes unrealistic. While completely changing the structure of donor programming is not a realistic goal, it is possible to adjust the programming within these parameters. Adjusting the targeted outcomes in donor programming to include norms or policy changes, even if incremental, and strengthening dialogues between youth and other key stakeholders, such as families, communities, and employers, would be welcome. These adjustments would need to be accompanied by stronger measurement tools for capturing these results. Through YouthPower, USAID started work to strengthen improved indicators for measuring PYD outcomes (Hinson et al., 2016), but continued work is needed on indicator definitions and measurement tools.

\section{Implications for Government and the Private Sector}

The CSYA body of work also points to future priorities regarding how to engage government and the private sector. Most assessments cited the existence of relevant national policies and government programs across multiple sectors and the policies were found to be well-written or well-intentioned. And yet, the policies were not effective nor implemented in practice and there 
were low levels of government funding available to support youth policies. As such, many assessments recommended more coordination, funding, oversight, and follow-through of the policies. Just as increased integration of PYD approaches into practice and decision making is needed among donors, many governments have only an emerging understanding of the PYD approach and could benefit from further support. Much more programming should be focused around innovative public-sector-youth partnerships to help governments tap into youth networks and youth leaders. As stated above, systems-oriented youth development programming, inevitably working through government institutions, is still among the most challenging to implement but in many ways this is the final challenge for ensuring sustainable impact. Expectations for PYD and government partners should be tailored to their varying levels of capacity and awareness. Some country governments may have existing mechanisms or entities that are already well-positioned to support youth and even "serve as a lead convener and coordinating body," whereas other countries may need more intensive support and prompting to help them adopt more youth-friendly approaches.

Youth assessments were also useful in highlighting the role of the private sector as an important stakeholder in youth programming. The youth assessments primarily promoted private-sector engagement as part of youth employment initiatives (e.g., shaping training curriculum to make it more market-driven, offering youth internships, and work-based learning). However, a few country assessments recognized that the private sector tended to be on the sidelines of reform. In fact, youth assessments and resulting youth programs have tended to take somewhat traditional approaches toward private-sector engagement, overlooking opportunities where employers and businesses can be brought into more innovative youth-employer partnerships. Innovative youth-employer partnerships can happen when businesses see youth as strategic partners, when there is a foundation of trust, and where businesses serve as advocates for youth because they see their potential and value. Therefore, we should build on youth assessments as useful tools for stimulating greater private-sector engagement but think more expansively and embrace businesses more broadly as significant stakeholders in youth program design and implementation.

\section{Conclusion}

This article outlined youth priorities, what helps and hinders them, and implications from those findings for practice and policy. If readers apply those recommendations, we can hope to see a decline in the pressing needs of youth globally. The PYD approach envisions young people as 
assets, who are engaged and empowered to reach their full potential and contribute in positive ways to their families, communities, and governments. Building awareness, improving coordination, and increasing the skills of actors supporting youth development will increase the effectiveness and consistency of youth programming and policies as part of the enabling environment. Youth must lead the design, implementation, and monitoring of these efforts. Going forward, it is essential that we evaluate youth programs to know what works well, for whom, and how much it costs, and that we disaggregate data by age bandings, gender, and vulnerability. There is an array of new resources available to support those efforts (Jessee \& Wolkoff, 2020).

\section{Author Note}

This article is made possible by the support of the American People through the United States Agency for International Development (USAID), under the terms of YouthPower 2: Learning and Evaluation AID Contract \# 47QRAA19D0006K/7200AA19M00018. The contents are the responsibility of the authors and do not necessarily reflect the views of USAID or the United States Government.

Declaration of interest: All authors are involved in the implementation or oversight of the referenced projects.

Correspondence concerning this article should be addressed to: Cassandra Jessee, $112020^{\text {th }} \mathrm{St}$. NW, Washington, DC 20011. Email: cassandra.jessee@gmail.com.

\section{References}

Allison, C., Jenderedian, G., Sargsyan, L., Proctor, H., \& Jessee, C. (2019). Armenia youth situational analysis. YouthPower Learning. https://www.youthpower.org/armenia-csya

Barsa, M., \& Sidatt, H. (2020). USAID/Mauritania cross-sectoral youth assessment report. YouthPower Learning and YouthPower2: Learning and Evaluation. https://www.youthpower.org/mauritaniacysa

Bell, P., Olenik, C., Alldredge, J., Moroz, E., Moore, A., O'Donnell, C., \& Jessee, C. (2019). Cross-sectoral youth assessment for USAID/Kyrgyz Republic (Final Assessment Report). YouthPower Learning. https://www.youthpower.org/kyrgyz-republic-csya 
Journal of Youth Development | http://jyd.pitt.edu/ | Vol. 16 Issue 2-3 DOI 10.5195/jyd.2021.1046

Listening to Youth: Program and Policy Implications

Benson, P. L., Leffert, N., Scales, P. C., \& Blyth, D. A. (1998). Beyond the "village" rhetoric: Creating healthy communities for children and adolescents. Applied Developmental Science, 2(3), 138159. https://doi.org/10.1080/10888691.2012.642771

Blum, R. (2018). Recommended strategic priorities: Positive youth development programming for USAID/Liberia. YouthPower Learning.

Blum, R., Jones, B., \& Ngeleza, R. (2017). Overview of youth development perspectives in Eastern Democratic Republic of Congo. YouthPower Learning. https://www.youthpower.org/drc-activity

Blum, R., N'Tow, S., Woolf, L., \& Jessee, C. (2019). USAID/Liberia youth situational analysis. YouthPower Learning. https://www.youthpower.org/liberia-youth-assessment

Boyson, J., Bitga, A., \& Desta, Z. (2017). Recommended strategic priorities: Positive youth development programming for USAID/Ethiopia. YouthPower Learning.

Catalano, R. F., Berglund, M. L., Ryan, J. A., Lonczak, H. S., \& Hawkins, J. D. (2002). Positive youth development in the United States: Research findings on evaluations of positive youth development programs. Prevention \& Treatment, 5(1), Article 15. https://doi.org/10.1037/15223736.5.1.515a

Catalano, R. F., Skinner, M., Alvarado, G., Kapungu, C., Reavley, N., Patton, G., Jessee, C., Plaut, D., Moss, C., Bennett, K., Sawyer, S. M., Sebany, M., Sexton, M., Olenik, C., \& Petroni, S. (2019, July). Positive youth development programs in low- and middle-income countries: A conceptual framework and systematic review of efficacy. Journal of Adolescent Health, 65(1), 15-31. https://doi.org/10.1016/j.jadohealth.2019.01.024

Catsum, M., \& Castro, A. (2019). Recommended strategic priorities: Positive youth development programming USAID/Honduras. YouthPower Learning.

Catsum, M., Castro, A., O'Donnell, C., Chard, E., \& Jessee, C. (2018). USAID/Honduras development objective youth assessment situational analysis. YouthPower Learning. https://www.youthpower.org/ethiopia-csya

Chowa, G., Masa, R., Manzanares, M., Bilotta, N., \& Barrington, C. (2021). A systematic review for positive youth development impacts on marginalized and vulnerable youth in low-and middleincome countries. YouthPower2: Learning and Evaluation. https://www.youthpower.org/resources/systematic-literature-review-positive-youth-developmentimpacts-marginalized-and-vulnerable-youth

Clarke, V., Braun, V., \& Hayfield, N. (2015). Thematic analysis. In J. A. Smith (Ed.), Qualitative psychology: A practical guide to research methods, (pp. 222-248). SAGE.

Desta, Z., Bitga, A., \& Boyson, J. (2018). USAID/Ethiopia cross-sectoral youth assessment situational analysis. YouthPower Learning. https://www.youthpower.org/ethiopia-csya 
Journal of Youth Development | http://jyd.pitt.edu/ | Vol. 16 Issue 2-3 DOI 10.5195/jyd.2021.1046

Listening to Youth: Program and Policy Implications

Eccles, J., \& Gootman, J. A. (2002). Community programs to promote youth development. National Research Council Institute of Medicine: National Academy Press.

Education Development Center. (2009). Guide to cross-sectoral youth assessments. Education Development Center. https://www.edu-links.org/resources/guide-cross-sectoral-youthassessments

FHI 360. (2019). Implementation guide: Youth programming assessment tool (YPAT). Author. https://www.edu-links.org/resources/youth-programming-assessment-tool-ypat

Green, K., \& Andrianaivosoa, L. M. (2020). USAID/Madagascar cross-sectoral youth assessment final report. YouthPower2: Learning and Evaluation.

Green, K., Woolf, L., Olenik, C. (2020). Youth assessments 101. YouthPower2: Learning and Evaluation https://www.youthpower.org/sites/default/files/YouthPower/files/resources/YOUTH\%20ASSESSM ENTS\%20BRIEF\%20FINAL.pdf

Green, K., Bagaye, E., Blum, R., Woolf, L., \& Jessee, C. (2019). USAID/Rwanda youth assessment. YouthPower Learning. https://www.youthpower.org/rwanda-youth-assessment

Hinson, L., Kapungu, C., Jessee, C., Skinner, M., Bardini, M., \& Evans-Whipp, T. (2016). Measuring positive youth development toolkit: A guide for implementers of youth programs. YouthPower Learning. Retrieved from https://www.youthpower.org/resources/positive-youth-developmentmeasurement-toolkit

International Federation of Red Cross and Red Crescent. (2020). What is vulnerability? Author. Retrieved September 2020, from https://www.ifrc.org/en/what-we-do/disaster-management/aboutdisasters/what-is-a-disaster/what-is-vulnerability/

International Foundation for Electoral Systems. (2016, September). Supporting meaningful global youth engagement. Author. https://www.ifes.org/news/supporting-meaningful-global-youthengagement

International Labour Organization. (2020). World employment and social outlook trends 2020. Author. https://www.ilo.org/wcmsp5/groups/public/---dgreports/---dcomm/--publ/documents/publication/wcms 734455.pdf

Jessee, C., \& Wolkoff, L. (2020). The YouthPower learning project: Advancing youth development. YouthPower Learning. https://www.youthpower.org/resources/final-report-youthpower-learningproject-advancing-positive-youth-development

Lerner, R. M. (2002). Concepts and theories of human development ( $3^{\text {rd }}$ ed.). Lawrence Erlbaum Associates.

Lerner, R. M. (2004). Liberty: Thriving and civic engagement among America's youth. Sage. 
Lerner, R. M., Almerigi, J. B., Theokas, C., \& Lerner, J. V. (2005). Positive youth development: A view of the issues. The Journal of Early Adolescence, 25(1), 10-16. https://doi.org/10.1177/0272431604273211

Lord, K. (2016, August 12). Here comes the young. Foreign Policy. https://foreignpolicy.com/2016/08/12/here-comes-the-young-youth-bulge-demographics/

Making Cents International. (2016). Workforce development and youth employment in Nigeria. YouthPower Learning. https://www.youthpower.org/nigeria-wfda

Nicholson, C., \& Walker, G. (2020). USAID/Eastern and Southern Caribbean cross-sectoral youth assessment situational analysis. YouthPower2: Learning and Evaluation.

Olenik, C., Darrow de Mora, D., Sohnen, N., \& Tines, J. (2020). USAID/Dominican Republic cross-sectoral youth assessment desk review report. YouthPower2: Learning and Evaluation.

Patton, G. C., Sawyer, S. M., Santelli, J. S., Ross, D. A., Afifi, R., Allen, N. B., Arora, M., Azzopardi, P., Baldwin, W., Bonell, C., Kakuma, R., Kennedy, E., Mahon, J., McGovern, T., Mokdad, A. H., Patel, V., Petroni, S., Reavley, N., Taiwo, K., . . Viner, R. (2016). Our future: a Lancet commission on adolescent health and wellbeing. Lancet, 38710036), 2423-2478.

https://doi.org/10.1016/S0140-6736(16)00579-1

Plan International. (2021). Youth voices in youth employment: A roadmap for promoting meaningful youth engagement in youth employment programs. Author. https://www.planusa.org/docs/Youth_Engagement Manual.pdf

Robinson, J. P., \& Winthrop, R. (2016). Millions learning: Scaling up quality education in developing countries. The Center for Universal Education at Brookings. https://www. brookings.edu/research/millions-learning-scaling-up-quality-education-indeveloping-countries/

Rutherford, D., \& Mirzoyants, A. (2020). USAID/Kenya youth assessment. YouthPower Learning. https://www.youthpower.org/kenya-cysa

Rutherford, D., Farah, O., Walanwal, F. K., \& Jessee, C. (2019). Recommended strategic priorities: Positive youth development programming for USAID/Somalia. YouthPower Learning.

Rutherford, D., Farah, O., Walanwal, F. K., Woolf, L., \& Jessee, C. (2020). USAID/Somalia youth assessment. YouthPower Learning. https://www.youthpower.org/somalia-csya

Sengezener, S., \& Mansare, S. (2020a). USAID/Guinea youth assessment situational analysis report. YouthPower Learning and YouthPower2: Learning and Evaluation.

Sengezener, S., \& Mansare, S. (2020b). Recommended strategic priorities: Positive youth development programming for USAID/Guinea. YouthPower Learning and YouthPower2 Learning and Evaluation. 
Journal of Youth Development | http://jyd.pitt.edu/ | Vol. 16 Issue 2-3 DOI 10.5195/jyd.2021.1046 Listening to Youth: Program and Policy Implications

Tihm, Y., Walker, G., Moore, A.-M., Moroz, E., \& Lapadatova, G. (2020). USAID/Morocco cross-sectoral youth assessment situational analysis report. YouthPower2: Learning and Evaluation.

United Nations. (2020). The world of work and COVID-19 (Policy Brief). Author. https://unsdg.un.org/sites/default/files/2020-07/policy-brief-the world of work and covid19.pdf

United Nations Department of Economic and Social Affairs Population Dynamics. (2020, September). World population prospects 2019. Author. https://population.un.org/wpp/DataQuery/

United Nations Children's Fund. (2019). Transitions from school-to-work. UNICEF. https://www.unicef.org/media/60366/file/Transitions-from-school-to-work-2019.pdf

U.S. Agency for International Development. (2012). Youth in development policy. Author. https://www.usaid.gov/policy/youth

Walker, G., Green, K., Douglas, Z., \& Chileshe, C. (2016). USAID/Zambia mission-wide youth assessment report. YouthPower Learning. https://www.youthpower.org/zambia-mwya

Woolf, L., Blum, R., Jessee, C., \& Olenik, C. (2017). Evidence review of cross-sectoral youth development approaches in conflict-affected environments. YouthPower Learning. https://www.youthpower.org/drc-activity

World Bank. (2018). The great schooling expansion-and those it has left behind. In World development report 2018. Author. https://openknowledge.worldbank.org/bitstream/handle/10986/28340/9781464810961 Ch02.pdf

World Bank. (2020). The World Bank data catalog. Author. https://datacatalog.worldbank.org/ World Health Organization. (2021, January 18). Adolescent and young adult health. WHO Newsroom. https://www.who.int/news-room/fact-sheets/detail/adolescents-health-risks-and-solutions 